\title{
Evidence for Heinrich event 1 in the British Isles
}

\author{
MARSHALL MCCABE*, JASPER KNIGHT and STEPHEN MCCARRON \\ School of Environmental Science, University of Ulster, Coleraine, County Londonderry BT52 1SA, Northern Ireland
}

McCabe, M., Knight, J. and McCarron, S. 1998. Evidence for Heinrich event 1 in the British Isles. J. Quaternary Sci., Vol. 13, pp. 549-568. ISSN 0267-8179.

Received 6 December 1997; Revised 26 May 1998; Accepted 2 June 1998

ABSTRACT: In the north Irish Sea basin (ISB), sedimentary successions constrained by AMS ${ }^{14} \mathrm{C}$ dates obtained from marine microfaunas record three major palaeoenvironmental shifts during the last deglacial cycle. (i) Marine muds (Cooley Point Interstadial) dated to between 16.7 and $14.7{ }^{14} \mathrm{C}$ kyr BP record a major deglaciation of the ISB following the Late Glacial Maximum (LGM). (ii) Terminal outwash and ice-contact landforms (Killard Point Stadial) were deposited during an extensive ice readvance, which occurred after $14.7{ }^{14} \mathrm{C} \mathrm{kyr} \mathrm{BP}$ and reached a maximum extent at ca.14 ${ }^{14} \mathrm{C}$ kyr BP. At this time the lowlands surrounding the north ISB were drumlinised. Coeval flowlines reconstructed from these bedforms end at prominent moraines (Killard Point, Bride, St Bees) and indicate contemporaneity of drumlinisation from separate ice dispersal centres, substrate erosion by fast ice flow, and subglacial sediment transfer to ice-sheet margins. In north central Ireland bed reorganisation associated with this fast ice-flow phase involved overprinting and drumlinisation of earlier transverse ridges (Rogen-type moraines) by headward erosion along ice streams that exited through tidewater ice margins. This is the first direct terrestrial evidence that the British Ice Sheet (BIS) participated in Heinrich event $1(\mathrm{H} 1)$. (iii) Regional mud drapes, directly overlying drumlins, record high relative sea-level (RSL) with stagnation zone retreat after $13.7{ }^{14} \mathrm{C}$ kyr BP (Rough Island Interstadial).

Elsewhere in lowland areas of northern Britain ice-marginal sediments and morainic belts record millennial-scale oscillations of the BIS, which post-date the LGM advance on to the continental shelf, and pre-date the Loch Lomond Stadial (Younger Dryas) advance in the highlands of western Scotland (ca. $11-10{ }^{14} \mathrm{C}$ kyr BP).

In western, northwestern and northern Ireland, Killard Point Stadial (H1) ice limits are reconstructed from ice-flow lines that are coeval with those in the north ISB and end at prominent moraines. On the Scottish continental shelf possible $\mathrm{H} 1$-age ice limits are reconstructed from dated marine muds and associated ice marginal moraines. It is argued that the last major offshore ice expansion from the Scottish mountains post-dated ca. $15{ }^{14} \mathrm{C} \mathrm{kyr}$ BP and is therefore part of the $\mathrm{H} 1$ event. In eastern England the stratigraphic significance of the Dimlington silts is re-evaluated because evidence shows that there was only one major ice oscillation post-dating ca.18 ${ }^{14} \mathrm{C}$ kyr BP in these lowlands.

In a wider context the sequence of deglacial events in the ISB (widespread deglaciation of southern part of the BIS $\rightarrow$ major readvance during $\mathrm{H} 1 \rightarrow$ ice sheet collapse) is similar to records of ice sheet variability from the southern margins of the Laurentide Ice Sheet (LIS). Welldated ice-marginal records, however, show that during the Killard Point readvance the BIS was at its maximum position when retreat of the LIS was well underway. This phasing relationship supports the idea that the BIS readvance was a response to North Atlantic cooling induced by collapse of the LIS. () 1998 John Wiley \& Sons, Ltd.

KEYWORDS: Heinrich event 1; British Isles; Killard Point Stadial; AMS ${ }^{14} \mathrm{C}$ dating; drumlinisation; iceflow lines.

\section{Introduction}

Data from Greenland ice-cores and North Atlantic marinecores indicate that the last deglacial cycle (ca. $21-13{ }^{14} \mathrm{C}$

* Correspondence to: Marshall McCabe, School of Environmental Science, University of Ulster, Coleraine, County Londonderry, BT52 1SA, Northern Ireland

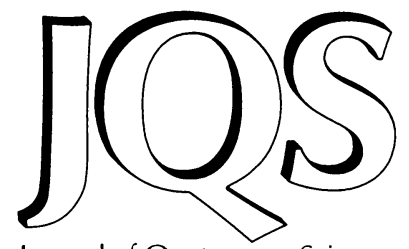

Journal of Quaternary Science kyr BP) was interrupted by millennial-scale climate shifts (Dansgaard et al., 1993; Bond and Lotti, 1995). Ice sheet variability in northwestern Europe, however, is not well documented from direct terrestrial field evidence, which should be present along emergent continental margins of the climatically sensitive northeastern Atlantic (McCabe and Clark, 1998).

At the Last Glacial Maximum (LGM; ca. $21{ }^{14} \mathrm{C}$ kyr BP) 
the British Ice Sheet (BIS) comprised a number of inland dispersion centres from which ice flowed on to the continental shelf (Bowen et al., 1986) (Fig. 1). Morainic belts and subglacial directional indicators show that, following the LGM, ice retreated towards separate dispersion centres located mainly in northern Britain (i.e. north central Ireland, Scottish Highlands, Southern Uplands, Pennines). Field evidence on coastal lowlands supports the hypothesis that significant BIS oscillations occurred during the last deglacial cycle (Trotter, 1929; Synge, 1969; Rose, 1985; Hall and Jarvis, 1989; Eyles et al., 1994; McCabe, 1996; Benn, 1997; Peacock, 1997). Although a crude ice-sheet rhythmicity (cycle of ice advance-retreat phases) can be identified from sedimentary and morphological records (McCabe, 1996; Knight et al., 1997), the phasing relations between BIS variability and that of other ice sheets in the amphi-North Atlantic, however, have not been established. Therefore it is difficult to evaluate links between records of glacial activity in Britain and the role of amphi-North Atlantic-interhemispheric connections of the ice-ocean-atmosphere system (Broecker and Denton, 1989).

The main thrust of this paper is to present $\mathrm{AMS}{ }^{14} \mathrm{C}$ dates integrated with stratigraphic evidence that constrain the age and anatomy of a major ice sheet readvance over the north central lowlands of Ireland and into the northern Irish Sea Basin (ISB; Fig. 1 and Table 1). This prominent readvance of part of the BIS at ca. $14{ }^{14} \mathrm{C}$ kyr BP provides the first evidence that the BIS participated in $\mathrm{H} 1$-linked ice-sheet activity. Assessment of regional palaeoenvironmental changes during the last deglacial cycle is based on data from positions of ice-sheet limits, the imprint of subglacial bedforms onshore, biostratigraphy of marine mud facies, AMS ${ }^{14} \mathrm{C}$ dating of marine microfaunas, and trends in relative sea-level (RSL; Fig. 2). Published stratigraphic and dating evidence for ice-sheet variability is then used to assess the limits and geomorphological impact of the $\mathrm{H} 1$ readvance, first in Ireland and then in other coastal zones around northern Britain.

\section{Methods and stratigraphic summary from the northwestern margins of the ISB}

Fossiliferous marine muds from five sites along the coast of eastern Ireland are identified from three critical levels within the deglacial stratigraphy (Stephens, 1963; McCabe, 1986, 1996). These data are summarised in Fig. 2 together with the results of AMS ${ }^{14} \mathrm{C}$ dates obtained from monospecific samples of the foraminifer Elphidium clavatum contained in these mud beds. The AMS ${ }^{14} \mathrm{C}$ dates (Table 1 ) together with lithostratigraphy provide a coherent time-frame for assessing



Figure 1 Ice flows and ice limits during the Killard Point Stadial in the northern Irish Sea basin. Inset shows generalised ice flows at the Late Glacial Maximum (LGM). 
Table 1 AMS ${ }^{14} \mathrm{C}$ ages from the Irish Sea Basin.

\begin{tabular}{|c|c|c|c|}
\hline Locality/description/comments & $\begin{array}{l}\text { Laboratory } \\
\text { number }\end{array}$ & $\delta^{13} \mathrm{C}$ & $\begin{array}{l}\text { Radiocarbon age } \mathrm{a}^{\mathrm{a}} \\
(\mathrm{yr} \mathrm{BP} \pm 1 \sigma)\end{array}$ \\
\hline $\begin{array}{l}\text { Rough Island: samples from marine mud draping drumlins. } \\
\text { Dates marine transgression after ice sheet collapse }\end{array}$ & AA 21822 & -2.089 & $12740 \pm 95$ \\
\hline $\begin{array}{l}\text { Killard Point: samples from marine mud interbedded in } \\
\text { outwash from the Killard Point moraine. Dates ice sheet } \\
\text { readvance }\end{array}$ & $\begin{array}{l}\text { AA } 22820 \\
\text { AA } 22821\end{array}$ & $\begin{array}{l}-2.607 \\
-2.702\end{array}$ & $\begin{array}{l}13785 \pm 115 \\
13955 \pm 105\end{array}$ \\
\hline $\begin{array}{l}\text { Cranfield Point: samples from interstadial mud below } \\
\text { outwash from the Carlingford Bay ice lobe. Dates ice-free } \\
\text { interval prior to readvance }\end{array}$ & $\begin{array}{l}\text { AA } 21818 \\
\text { AA } 21819\end{array}$ & $\begin{array}{l}-2.097 \\
-1.407\end{array}$ & $\begin{array}{l}14705 \pm 130 \\
15605 \pm 140\end{array}$ \\
\hline $\begin{array}{l}\text { Cooley Point: samples from interstadial mud below } \\
\text { outwash from the Dundalk Bay ice lobe. Records ice-free } \\
\text { interval prior to readvance }\end{array}$ & $\begin{array}{l}\text { AA } 17693 \\
\text { AA } 17694 \\
\text { AA } 17695\end{array}$ & $\begin{array}{l}-2.4 \\
-2.5 \\
-2.5\end{array}$ & $\begin{array}{l}15020 \pm 110 \\
15390 \pm 110 \\
15400 \pm 140\end{array}$ \\
\hline $\begin{array}{l}\text { Kilkeel: samples from interstadial mud below outwash } \\
\text { from the Carlingford Bay ice lobe. Dates ice-free interval } \\
\text { prior to readvance }\end{array}$ & $\begin{array}{l}\text { AA } 22351 \\
\text { AA } 22352\end{array}$ & $\begin{array}{l}-2.019 \\
-2.375\end{array}$ & $\begin{array}{l}16760 \pm 130 \\
16750 \pm 160\end{array}$ \\
\hline
\end{tabular}

${ }^{a} \mathrm{AMS}{ }^{14} \mathrm{C}$ ages from monospecific samples of Elphidium clavatum in marine muds. Samples corrected for assumed $400 \mathrm{y}$ difference between surface-water carbon and atmospheric carbon.

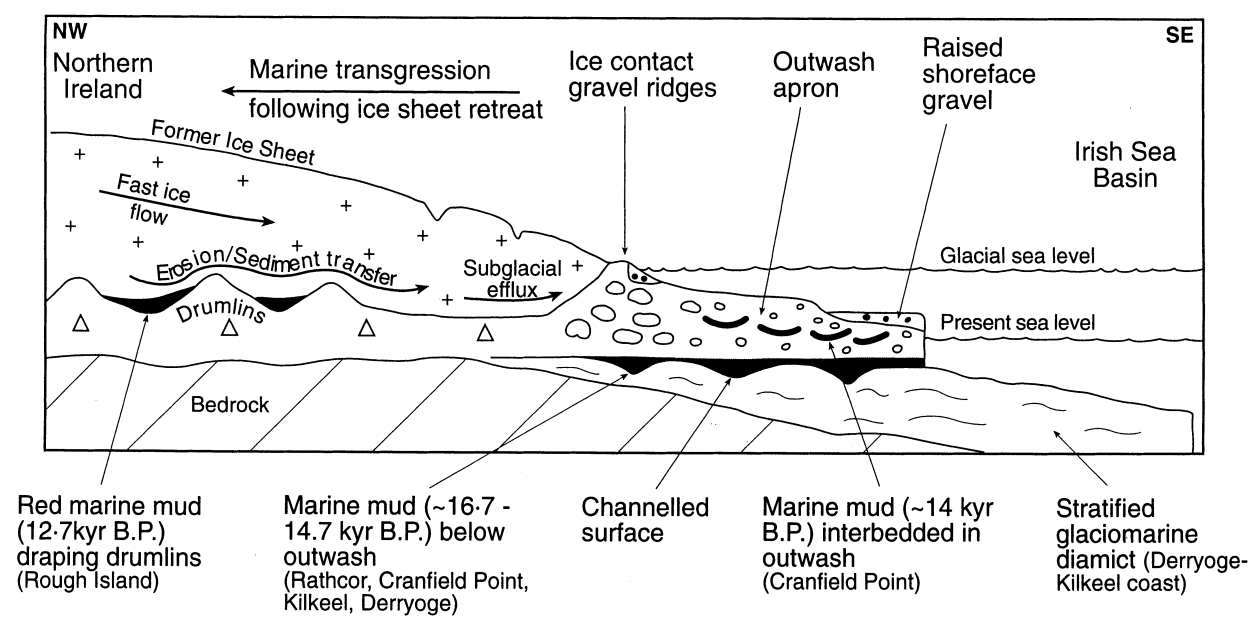

Figure 2 Cartoon of the glacigenic system operating during the Killard Point Stadial in the northern Irish Sea basin showing the relationships between subglacial bedforms, dated marine muds, lithostratigraphy, relative sea-level and terminal outwash.

major palaeoenvironmental changes during the final deglaciation of coastal margins of the ISB. Major palaeoenvironmental shifts include (i) widespread deglaciation of coastal zones (Cooley Point Interstadial, $\geq 16.7-14.7{ }^{14} \mathrm{C}$ kyr BP), (ii) ice advance into the northern ISB with drumlinisation of adjacent lowlands (Killard Point Stadial, after $14.7{ }^{14} \mathrm{C}$ kyr BP and maximum ice position at $14.0{ }^{14} \mathrm{C} \mathrm{kyr} \mathrm{BP}$ ), and (iii) rapid deglaciation with stagnation zone retreat (Rough Island Interstadial, after $13.7{ }^{14} \mathrm{C}$ kyr BP) (Fig. 2). The AMS ${ }^{14} \mathrm{C}$ dates show that the Killard Point Stadial is part of the $\mathrm{H} 1$ event and provides the first direct terrestrial evidence of BIS participation in $\mathrm{H} 1$.

The microfaunas in these mud beds are all remarkably similar as they are dominated by E. clavatum (85-95\%) and the ostracod Roundstonia globulifera (5-10\%), which shows intact instars (McCabe and Haynes, 1996). The vast majority (>95\%) of foraminifer specimens show pristine, glossy preservation and a range of test sizes with no sign of reworked temperate forms. This faunal assemblage is therefore compositionally distinct from other derived and mixed assemblages found in meltwater mud drapes around the ISB, which were reworked along subglacial feeder channels (e.g. Austin and McCarroll, 1992; McCarroll and Harris, 1992). Because the eastern Ireland mud beds are undeformed with a marked regional distribution and occur above, below and within deglacial facies we conclude that they provide unequivocal evidence for shallow water, glaciomarine deposition around the margins of the retreating ice masses in the northwestern ISB (Haynes et al., 1995).

Opportunistic biocoenoses similar to that in the deglacial stratigraphy of the northwestern ISB have been recorded from contemporary Arctic-subarctic areas recently vacated by tidewater glaciers. Hald et al. (1994) found that the present distribution of $E$. clavatum corresponds to cold $(0.5$ to $1.8^{\circ} \mathrm{C}$ ), turbid and shallow waters of variable salinities $(\sim 33 \%)$ and high sedimentation rates. In addition, on the basis of its present environmental controls, these authors suggest that $E$. clavatum recovered from marine cores (ca. $70 \%$ of total microfauna) on the Svalbard-Barents Sea margin is diagnostic of a marked meltwater event between 14 and $13{ }^{14} \mathrm{C}$ kyr BP. The marked $\delta^{16} \mathrm{O}$ peak in the foraminifer tests is interpreted as a major meltwater pulse from the 
Barents Sea and Fennoscandian ice sheets, confirming the view of Vilks (1981) that assemblages dominated by $E$. clavatum are typical of the cold, diluted waters produced by the melting of large ice sheets.

\section{Ice limits along the northwestern margins of the Irish Sea Basin}

The outer limit $(130 \mathrm{~km}$ long) of the last southeasterly icesheet advance from the north Irish lowlands is marked by a prominent (1-3 km wide) terminal zone of ice-contact facies and landforms (Fig. 3) (Stephens and McCabe, 1977). This ice limit is represented by ridges and hummocks between Killard Point and Ardglass, and outwash spreads and ridges flanking the outer margins of Carlingford Bay and Dundalk Bay (Fig. 3) (McCabe et al., 1984, 1987; McCabe, 1986). Contemporaneity between these ice limits is shown by the presence of raised late-glacial shoreface facies found only immediately outside these ice limits (Eyles and McCabe, 1989; Haynes et al., 1995).

Drumlins and subglacially streamlined ridges occur to within $1-6 \mathrm{~km}$ of the ice-contact terminal zone (Fig. 3). Colinear ice-flow lines reconstructed from these bedforms indicate contemporaneity of drumlinisation (fast ice flow, subglacial sediment streamlining, and sediment transfer to ice margins) and terminal moraine building. Regionally, drumlinisation occurred along a series of curved flow paths that ended in prominent marine embayments (Fig. 3). These flow paths are identified morphologically as funnel shaped sectors that extend inland into and across a prominent northeast to southwest zone of transverse subglacial ridges (Fig. 4A). The northwest-southeast drumlinised grain therefore overprints and moulds the earlier transverse ridges, which are similar morphologically to Rogen moraines (Fig. 3 ). The general absence of streamlining and bed reorganisation within the main zone of pristine (unmodified) Rogen moraine inland, and the convergence of colinear ice-flow lines into Dundalk Bay, suggest that this drumlinising flow stage occurred by headward erosion of ice streams northwestwards into the Rogen moraine (Fig. 3).

\section{Deglacial facies along the northwestern margin of the Irish Sea Basin}

During the LGM the ISB was occupied by a southwardmoving ice stream fed from centres of ice dispersion on adjacent land masses (Fig. 1). On basin margins deglaciation patterns are shown by offlapping ridges/hummocky moraines and morainal banks that record rapid northward ice evacuation of the basin enhanced by tidewater calving (Eyles and McCabe, 1989). Along northwestern basin margins, facies successions from five critical exposures document three main events within the deglacial stratigraphy (Fig. 3). The facies successions that underpin these events will be described according to the dated stratigraphy from each site, and related to evidence for ice-sheet variability on the basin margins.

\section{Kilkeel-Derryoge}

Between Kilkeel and Derryoge three main facies are exposed in a coastal section $2 \mathrm{~km}$ long (Fig. 5A-D). Immediately above present beach level variably stratified diamict $(<8 \mathrm{~m}$ thick) comprises matrix-supported, texturally variable, flatlying stacked diamict beds, which are interbedded with gravelly lenses and sandy-muddy laminae. Discontinuous cobble and boulder lags $(<4 \mathrm{~m}$ long $)$ are common. Clasts up to boulder size are dispersed and may deform underlying diamict beds. Clast upper surfaces are often draped by parallel-laminated (millimetre to centimetre scale) silt and sand.

Graded, interbedded and planar to channelised contacts indicate that the sediment pile accumulated with only minor sequence breaks. Rapid vertical changes in texture and close association with a range of flow structures suggests that the diamict was deposited by a combination of subaqueous processes, including suspension fall-out, mass flows, traction current activity, ice-rafting and winnowing (McCabe, 1986).

Variability in clast lithology and a dominance $(\sim 60 \%)$ of glacially facetted types within the diamict record glacigenic input from ice masses located in the ISB, in the Mourne Mountains, and at the mouth of Carlingford Lough (Fig. 5C). Distinct sediment inputs from these different geological provinces suggest that sediment filled a depressed basin on the Mourne Plain as ice decayed generally northwards from the Irish Sea (Fig. 5C). During this deglacial phase the topographic barrier of the Mourne Mountains influenced ice supply and movement from the north and forced ice-sheet configuration into three separate ice-margin positions (Fig. $5 \mathrm{~B}$ and C) (McCabe, 1986). This deglacial stage was therefore marked by the release and resedimentation of large volumes of heterogeneous debris into a subaqueous setting. Regional evidence from morainal banks that are contemporaneous with late-glacial raised beaches indicates that the deglacial successions of stratified diamict are best explained by rapid tidewater evacuation of the basin (Eyles and McCabe, 1989).

Channels (100-200 m wide) incised into the uppermost parts of the diamict facies are infilled with rhythmically bedded muds ( $<7 \mathrm{~m}$ thick) containing isolated cobbles. Along some channel flanks intraformational soft-sediment slump structures testify to high sedimentation rates and a low-strength, dominantly muddy substrate (Lowe, 1976). Some horizontally bedded and undeformed sand-mud couplets are similar to interlaminated glaciomarine sediments (cyclopels) described by Mackiewicz et al. (1984) and result from interactions between overflows/underflows and oscillatory bottom currents. Detailed measurements of these couplets reveal an upward decrease in bed thickness and in sand/mud ratios, which reflect increasing distance from the sediment input point, coupled to a decrease in direct meltwater activity and, by inference, local ice volumes (McCabe, 1986). The marked absence of coarse-grained detritus in the mud indicates that the ice margins had retreated north of the Mourne Plain margins (Fig. 5C).

Both diamict and mud facies are truncated abruptly by a horizontal erosional surface, which is marked by a lag of cobbles and boulders one clast thick. The overlying lowangle cross stratified sand and gravel forms part of an extensive (ca. $18 \mathrm{~km}$ long) late-glacial raised beach system (up to $31 \mathrm{~m}$ a.s.I.) along this coastal sector (Stephens and McCabe, 1977).

The overall facies succession (diamict apron $\rightarrow$ mud-filled channels $\rightarrow$ emergent beach) can be interpreted in terms of deposition from rapidly retreating tidewater glaciers followed 


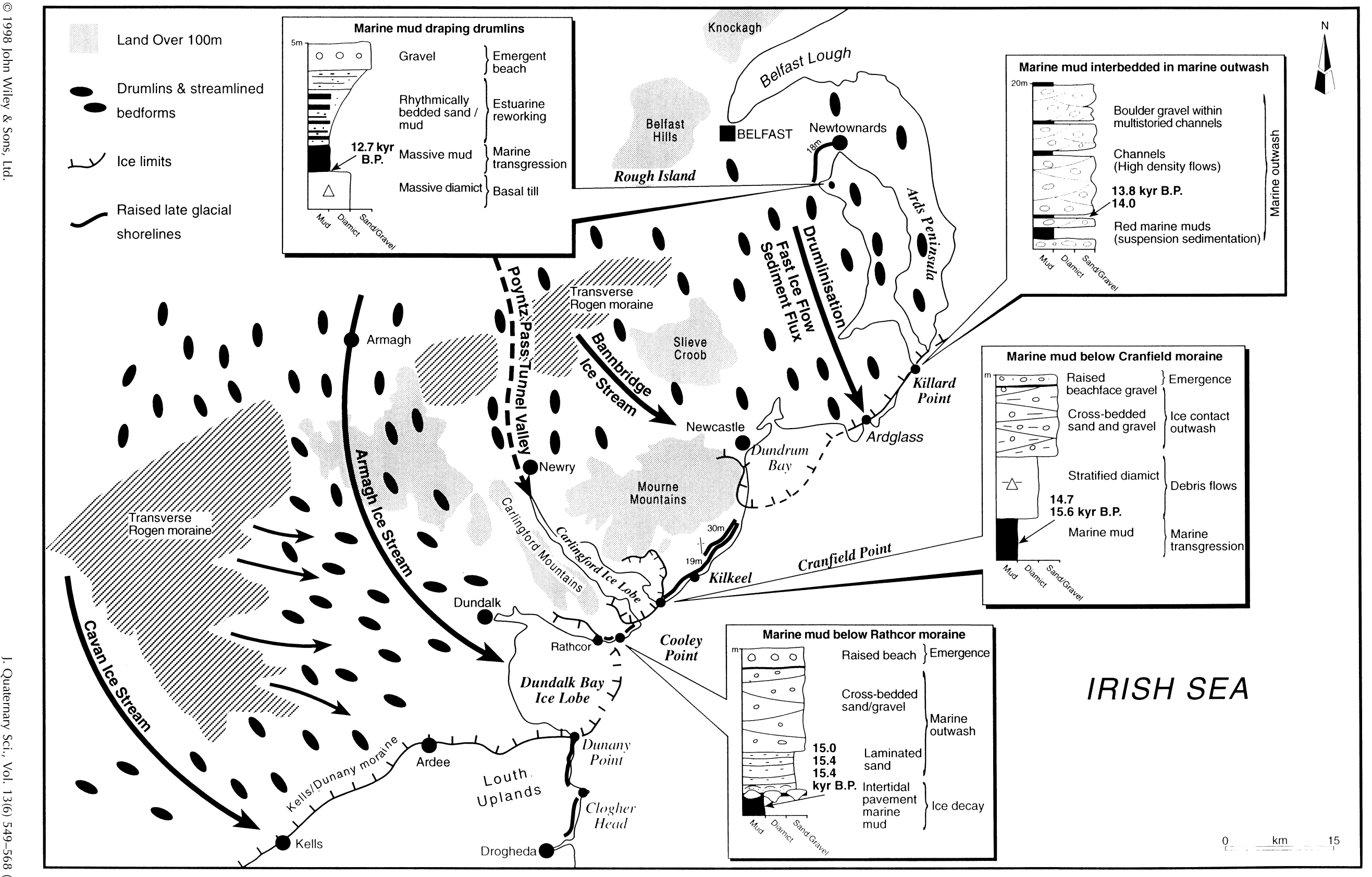

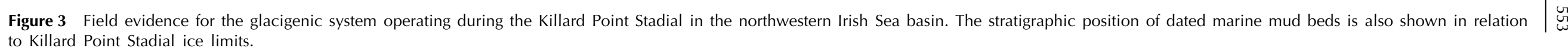



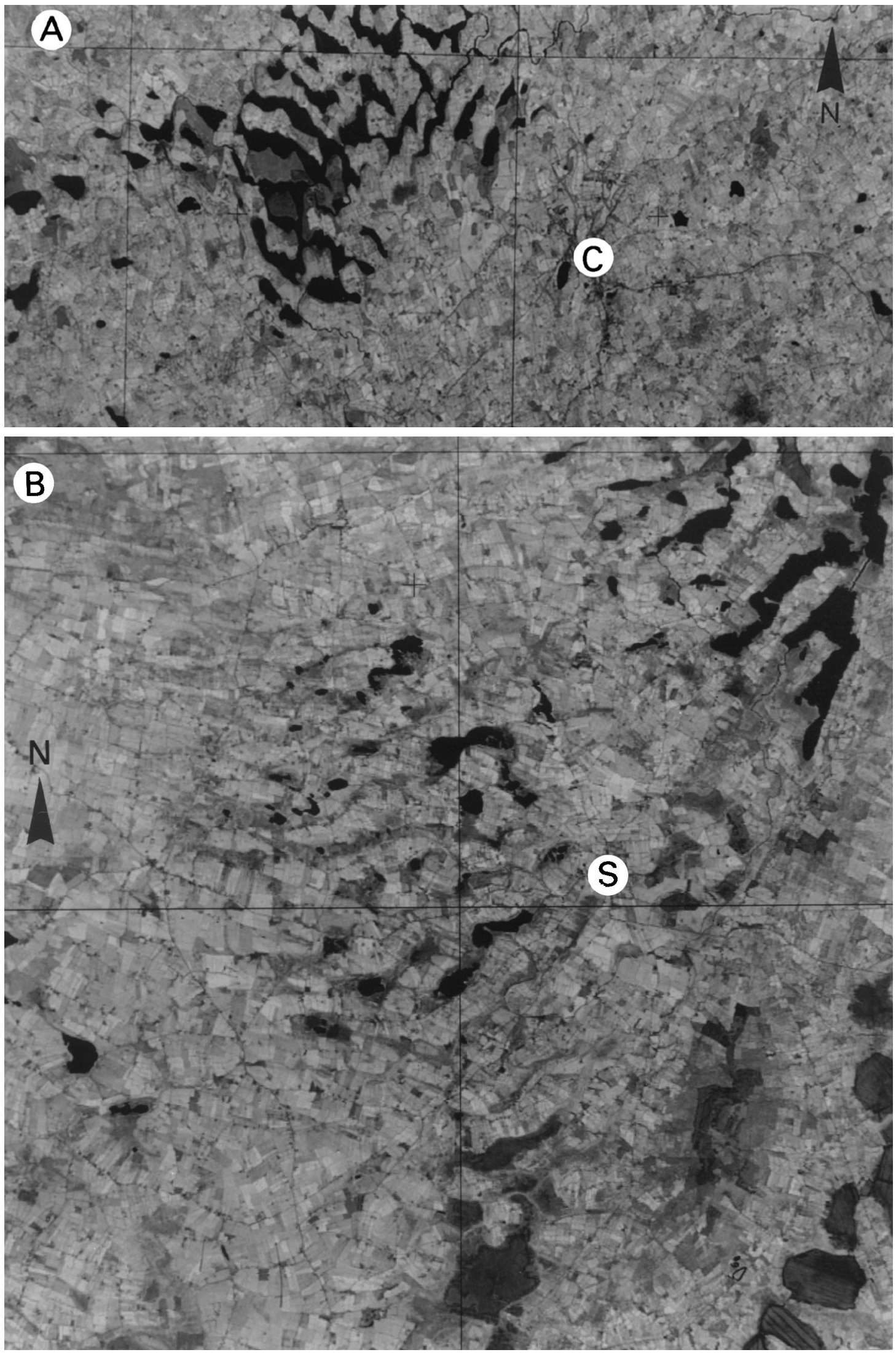

Figure 4 (A) Satellite image of flow-transverse (NE-SW) subglacial ridges (Rogen moraines), Cavan (C), north central Ireland. Ice flow from the northwest; grid squares are $10 \mathrm{~km}$ wide. The transverse ridges are overprinted and moulded by ice flows moving southwards during the Killard Point Stadial. (B) Satellite image of flow-transverse, subglacial ridges (Rogen moraines) near Strokestown (S), County Roscommon, central Ireland. Grid squares are $10 \mathrm{~km}$ wide. These ridges are overprinted by drumlins and flutes cut during the Killard Point Stadial by ice moving to the west. 


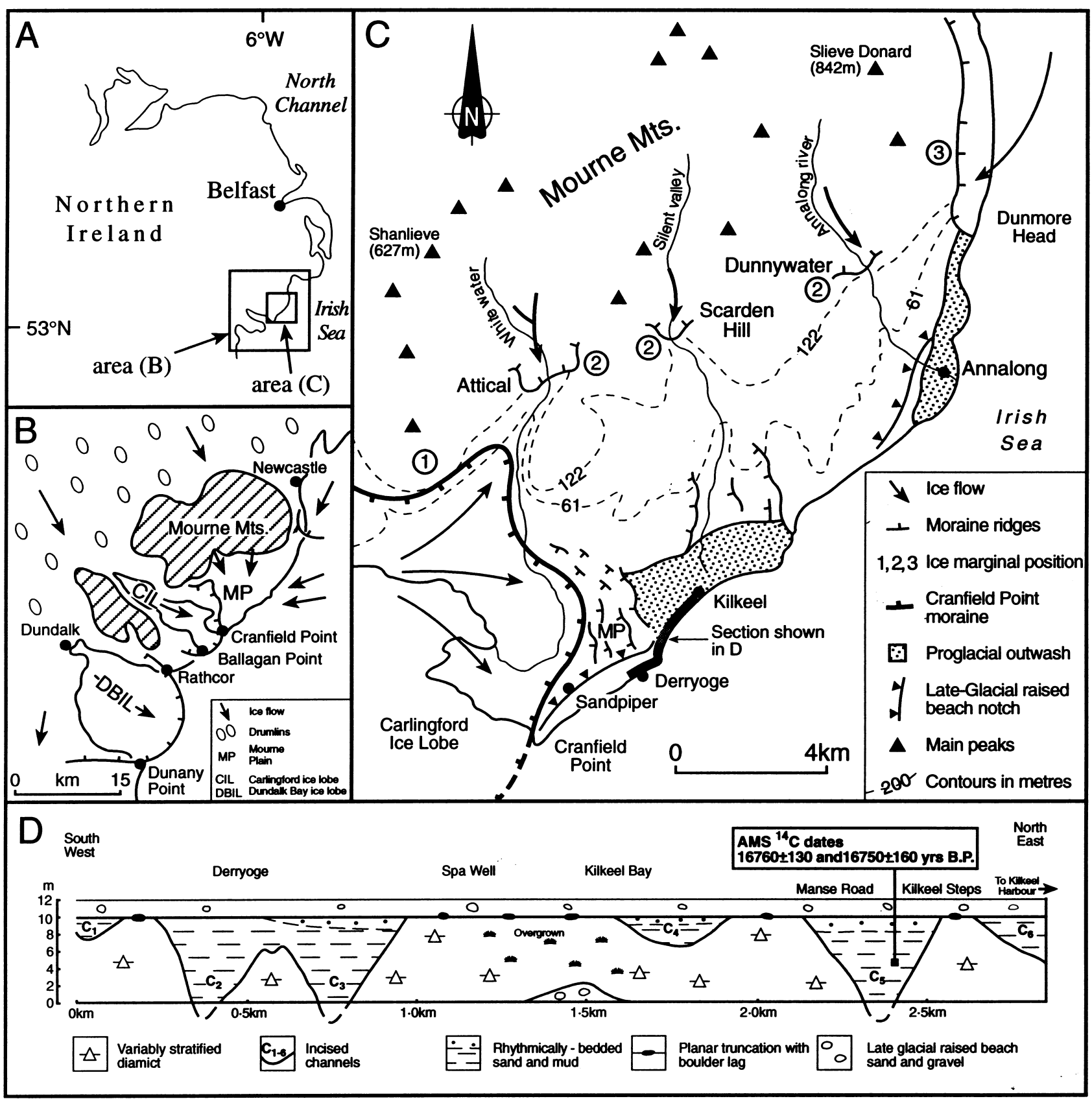

Figure 5 Deglacial patterns, ice limits and stratigraphy in south County Down, Northern Ireland. (A) Location of study area in Northern Ireland. (B) Killard Point Stadial ice limits, ice flows and position of ice lobes, eastern Ireland. (C) Moraines and ice limits at the margin of the Carlingford ice lobe and location of sites referred to in text. Note the topographic influence of the Mourne Mountains on sequential positions (1-3) of the ice sheet margins. (D) Generalised geometry of deglacial succession exposed along the Derryoge-Kilkeel coast and location of the site used to date the interstadial marine muds.

by glacioisostatic emergence. Because the deeply incised channels in the diamict pass below present sea-level they record a lowstand in RSL during the overall deglacial cycle, which was characterised mainly by high RSLs (McCabe, 1996, 1997).

\section{Cranfield Point}

At Cranfield Point (Fig. 5C) marine muds (1.5 m thick) comprise millimetre-scale fine-sand-mud couplets. These rhythmically bedded sediments are similar to those at Kilkeel, although massive mud beds (centimetre scale) within this facies are more common and isolated clasts are rare. The upper surface of the mud is planar and overlain by more than $4 \mathrm{~m}$ of crudely bedded diamict composed of angular and glacially facetted clasts set in a granule to pebble matrix. Discontinuous and very irregular bed contacts are marked mainly by abrupt changes in sediment texture. Clasts, particularly of boulder size, are arranged chaotically with $a b$ planes plunging at variable angles $\left(0-90^{\circ}\right)$. These characteristics suggest that the diamict was deposited by mass flows (Lowe, 1982).

The diamict forms part of the Cranfield Point moraine, which fronted a regional southeastwards ice readvance from the Irish lowlands into Carlingford Lough (Fig. 5B) (McCabe et al., 1992). Arcuate moraine ridges (ca. $30 \mathrm{~m}$ high) define former ice margins on both sides of Carlingford Lough (Fig. 5B). Steep ice-contact slopes face westwards towards the 
former ice tongue depression; outer (distal) slopes grade eastwards into spreads of thinly bedded (centimetre scale), coarse sandy diamict around Sandpiper (Fig. 5C). This diamict facies contains a wide range of clast sizes (pebbles to boulders) many of which deform underlying beds and are draped by sandy laminae.

The association of thin sandy beds with outsized clasts can be related to deposition from quasi-continuous sandy underflows and ice rafting from a grounded ice margin immediately to the west of Sandpiper (McCabe et al., 1992). Marine conditions at the ice margin are confirmed by the presence of raised late-glacial beach deposits and erosional notches immediately outside the Cranfield ice limit but not within the ice tongue depression, which was occupied by the grounded Carlingford ice lobe (Figs 3 and 5C). Inland (6-7 km northwestwards) from the terminal outwash, streamlined bedforms trending northwest-southeast depict the terrestrial element of this integrated glacial system (Fig. 3). This close field association clearly marks subglacial erosion and sediment transfer to tidewater ice margins during drumlinisation.

\section{Cooley Point}

Exposures (200 m long) of marine mud (1.5 m thick) at Cooley Point are part of a regional mud drape exposed intermittently along the northern shore of Dundalk Bay (McCabe and Haynes, 1996) (Fig. 6). The mud is variably but delicately laminated with numerous sandy stringers $(<0.5 \mathrm{~cm}$ thick) and occasional small pebbles. A boulder facies, comprising a bed of single clasts with local concentrations of near-touching clasts, is embedded across the upper surface of the mud, forming a prominent pavement. Deformed mud pillars occur between the near-touching boulders. The pavement upper surface is undulating and the upper surfaces of individual clasts are strongly bevelled and show cross-cutting striations. Similar pavements formed across subarctic tidal flats have been recorded by many authors (e.g. Dionne, 1981).

The platform surface is draped by alternating silt-sand laminae, which are overlain by cross-bedded sand and gravel contained within shallow scours $(2 \mathrm{~m}$ across). These facies are part of an apron of outwash associated with an ice limit marked by a well-defined ice-pushed moraine ridge at Rathcor, $1.8 \mathrm{~km}$ to the east (Fig. 7A). A late-glacial raised beach (ca. $20 \mathrm{~m}$ a.s.I.) at Templetown directly overlies this outwash and occurs immediately outside (i.e. distal to) the ice limit at Rathcor (Fig. 3). It is argued that the outwash at Cooley Point was deposited largely below wave-base because there is no stratigraphic evidence in the form of tidal/current winnowing or truncation towards the top of the outwash facies even though it is overlain by raised beach facies. The stratigraphy therefore suggests that the raised beach reflects a fall rather than a rise in RSL following deposition of subaqueous outwash (Fig. 6). The overall facies succession (open-water muds $\rightarrow$ intertidal boulder pavement $\rightarrow$ subaqueous outwash/beach) records shallow-water marine environments followed by an ice advance into Dundalk Bay
FACIES

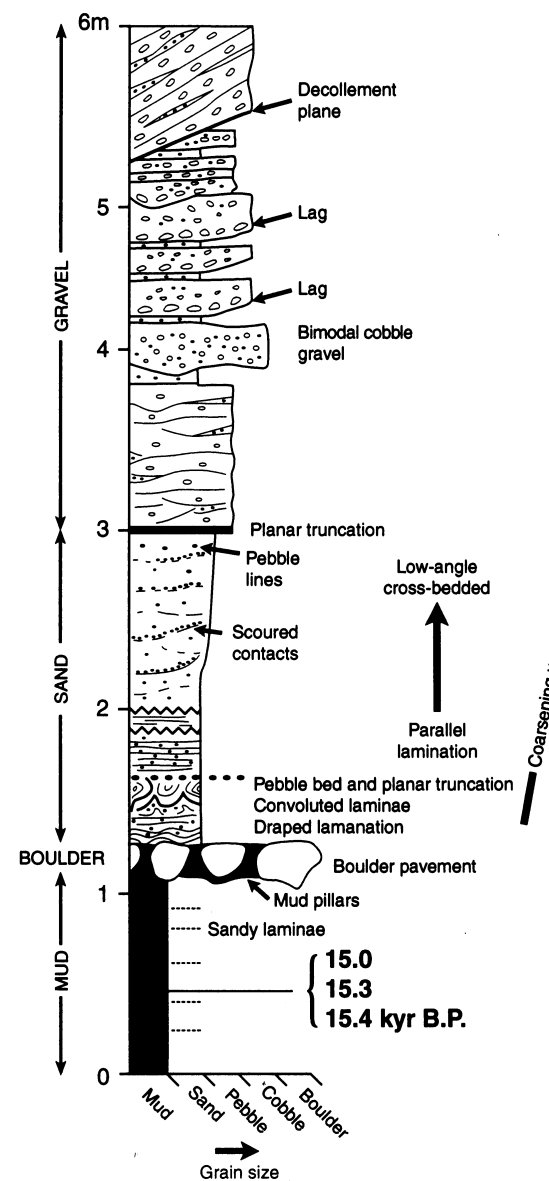

LITHOFACIES DESCRIPTION

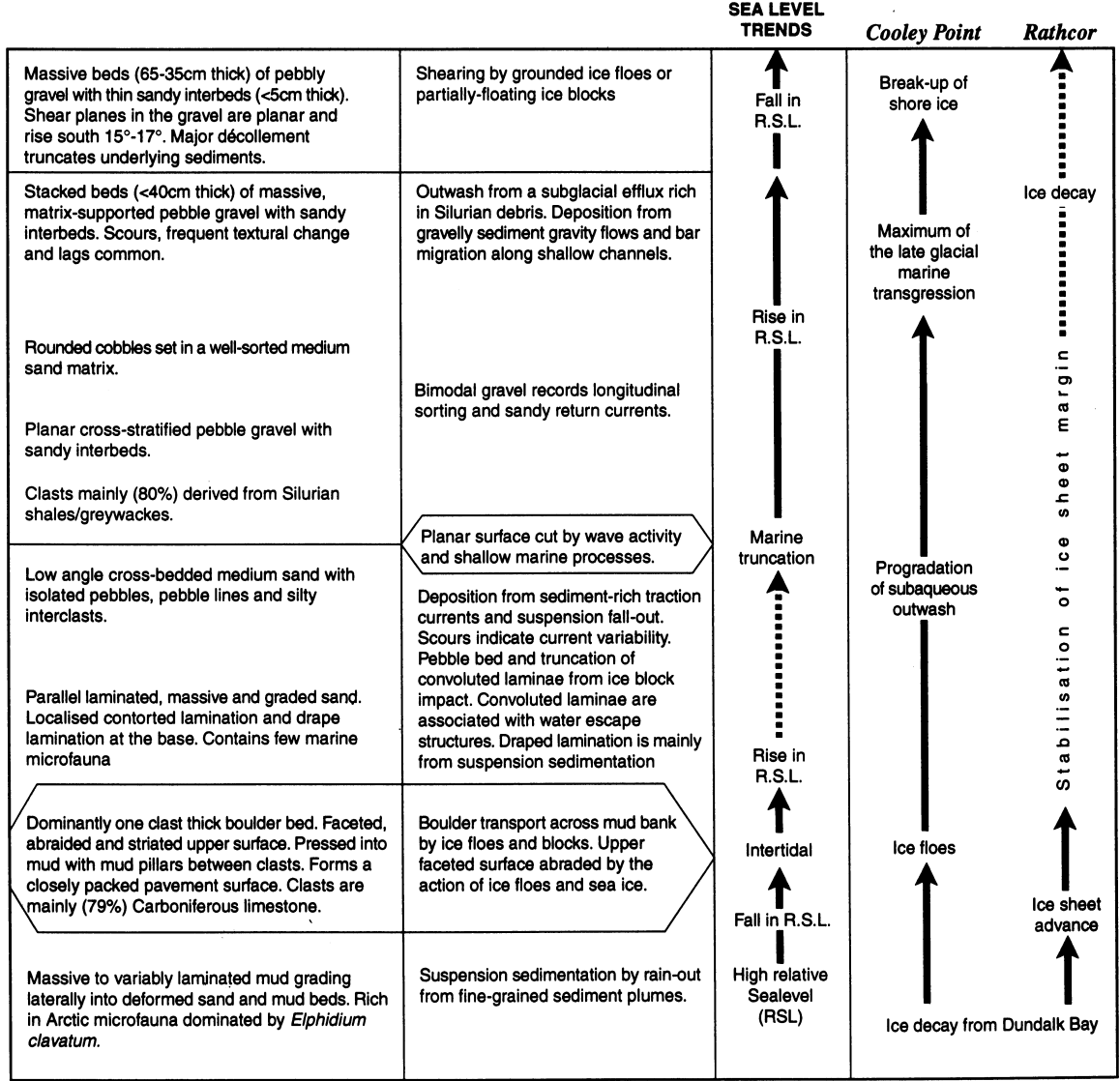

Figure 6 Measured log from Cooley Point summarising the main sedimentary structures in the mud, boulder, sand and gravel facies, the contact relationships and inferred processes, sea-level trends and events (after McCabe and Haynes, 1996). 

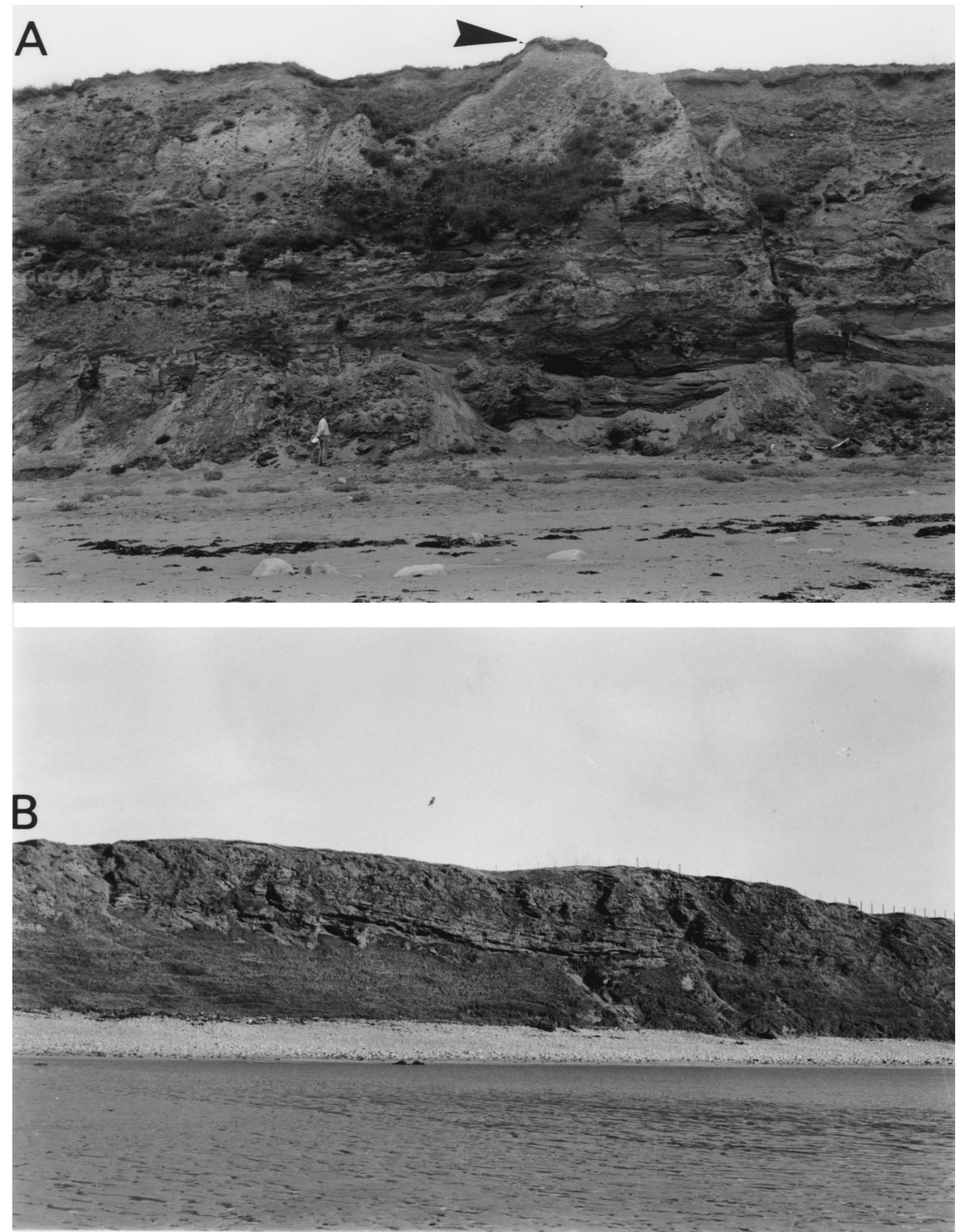

Figure 7 Terminal deposits of the Killard Point Stadial in eastern Ireland (A) Section in ice-thrust diamict forming the core of the Rathcor moraine (arrowed) on the north shore of Dundalk Bay. The moraine overlies marine outwash. Section is $21 \mathrm{~m} \mathrm{high.} \mathrm{(B)} \mathrm{Large} \mathrm{(ca.} 150 \mathrm{~m}$ across) subaqueous channel containing stacked beds of gravel forms part of the Killard Point moraine, County Down, Northern Ireland. Marine muds lining the base and sides of this channel are AMS ${ }^{14} \mathrm{C}$ dated to ca. $14 \mathrm{kyr}$ BP and formed at the maximum extent of ice in this area.

(Fig. 6). The terminal moraines marking this advance at Rathcor and Dunany Point (10-20 m high) are composed of interbedded diamictic mud, coarse-grained diamict, sand and gravel, recording shallow glaciomarine sedimentation along the margins of a grounded ice lobe (McCabe et al., 1987).

\section{Killard Point}

A northeast to southwest zone (ca. $1 \mathrm{~km}$ wide) of hummocky topography borders drumlin swarms for $9 \mathrm{~km}$ between Killard
Point and Ardglass (Fig. 8A). At Killard Point the facies succession rests directly on striated bedrock (Fig. 8B). On this glaciated surface stratified diamict ( $4 \mathrm{~m}$ thick) consists of stacked, massive planar beds that are clast-to-matrix supported, contain a wide range of clast sizes (granules to boulders) and are often separated by stringers of granules or coarse sand. Many clast $a b$ planes lie parallel to bedding planes. Shallow scours (1-2 $\mathrm{m}$ across) infilled with interbedded mud, sand, gravel and diamict occur within and towards the top of the massive diamict facies and show that diamict beds were deposited by mass flows (McCabe et al., 1984). The diamict is overlain by laminated and graded sand containing discontinuous mud laminae, water-escape structures, 


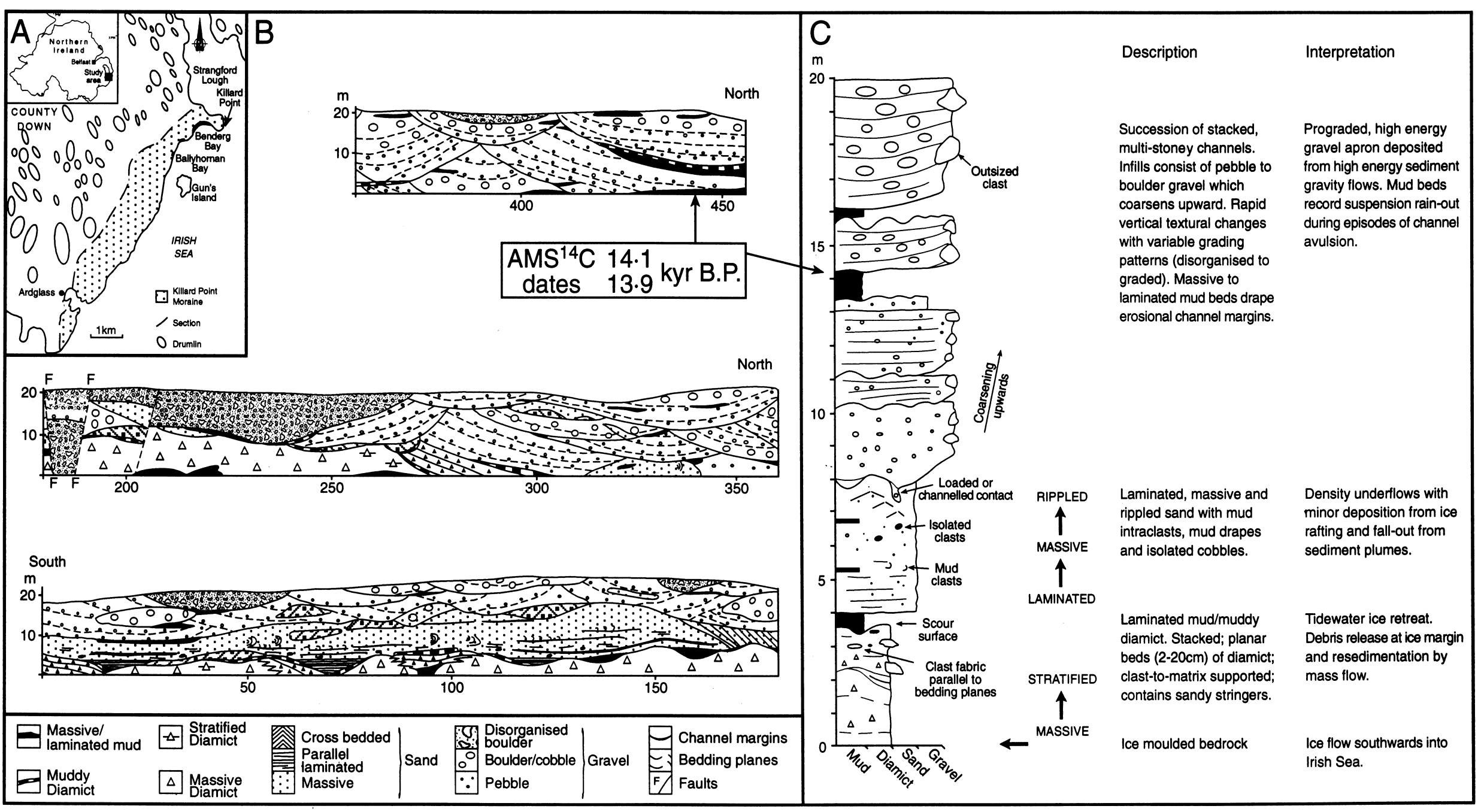

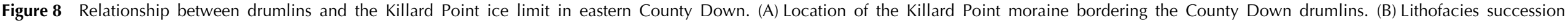
exposed at Benderg Bay, Killard Point, County Down (after McCabe et al., 1984). (C) Schematic log of lithofacies succession at Killard Point. 
mud rip-up clasts, flow folds and occasional isolated cobbles. Dominant transport mechanisms involve sediment gravity flows of low to intermediate viscosity (Middleton and Hampton, 1976) driven by density currents.

The upper surface of the sand facies is channelised and marked locally by intruded soft-sediment gravel dykes. The overlying gravel facies occurs as a set of 14 stacked and infilled channels (50-100 m across, 10-15 m deep) (Fig. 7B). Channel infills are dominated $(80 \%)$ by a range of boulder facies with subordinate sand and pebble facies. Individual beds vary in thickness $(0.2-1 \mathrm{~m})$ and are generally massive. Both distributional and coarse-tail grading patterns are occasionally present, together with boulder clusters. Bed contacts are sharp and parallel channel margins (Fig. 7B). Overall the gravel facies coarsen upwards within individual channels and channel axes indicate southward progradation. Stacked deposits of this type are similar sedimentologically to models for resedimented subaqueous conglomerates (Walker, 1975). Variable grading patterns together with evidence (outsized clasts) for clast freighting (Postma et al., 1988) suggest deposition by mass flows in which there were strong grain interactions and high dispersive pressures (Hein, 1982).

The margins of the most northerly channels are draped conformably by red mud ( $<1 \mathrm{~m}$ thick) containing an in situ marine microfauna dated to ca. $14{ }^{14} \mathrm{C}$ kyr BP (Killard Point Stadial) (Fig. 8C) (Table 1). Mud laminae are massive or normally graded and are interbedded conformably with muddy diamict. Together these facies record suspension deposition and traction current activity following channel avulsion, suggesting that erosion and sedimentation events alternated rapidly as the sediment pile accumulated. The conformable association of gravel and mud facies reflects rapid sediment input from a glacial efflux jet at the icegrounding zone, which was followed by gravity-driven resedimentation into deeper water. Drumlins, located a few kilometres inland, are perpendicular to the zone of terminal outwash between Killard Point and Ardglass and are therefore interpreted as part of the same integrated glacial system that operated during the Killard Point Stadial (Fig. 9). This system comprised southeasterly ice flow and associated drumlinisation, substrate erosion and sediment transfer to tidewater ice-margins.

\section{Rough Island}

North of Killard Point, drumlins near the coast are draped by red marine clay up to about $20 \mathrm{~m}$ a.s.I. (Stephens, 1963) (Fig. 3). At Rough Island near the northern end of Strangford Lough (Fig. 3) unweathered basal till is overlain directly by

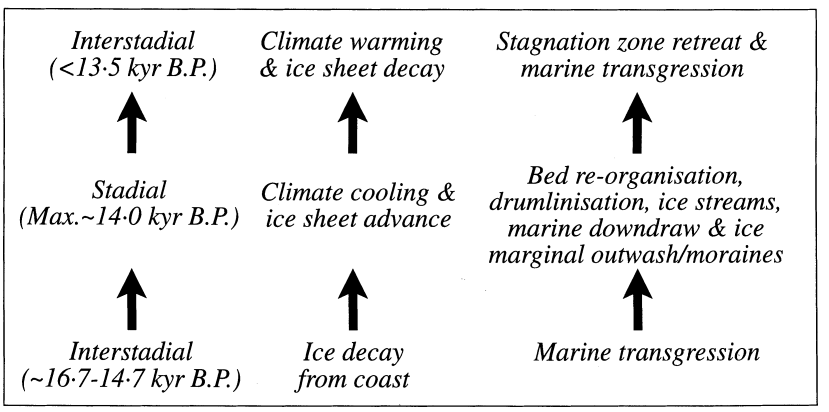

Figure 9 Summary of the main palaeoenvironmental changes before, during and after the Killard Point Stadial in the north Irish Sea area. rhythmically bedded sand and mud ( $<3 \mathrm{~m}$ thick). Massive mud beds occur at the base of the section and are gradually replaced upwards by interlaminated sand and mud. Marine microfaunas are well-preserved in the basal $20 \mathrm{~cm}$ (massive mud) and these were sampled for AMS ${ }^{14} \mathrm{C}$ dating. Upwards the microfaunas become less abundant and tests become stained and broken. This evidence, together with the upward increase in well-sorted sand laminae, suggests that mud rainout from suspension was replaced progressively by estuarine reworking during a falling RSL stage. Morphologically these reworked deposits form extensive flat terraces (ca. $20 \mathrm{~m}$ a.s.l.) at the head of the lough, and less conspicuous sediment drapes below late-glacial notches on drumlin flanks (Stephens, 1963; McCabe, 1997). Extensive late- and postglacial erosion within the lough is also evident from residual patches, reefs and larger islands ('pladdies') marked by lags of large clasts that represent the remains of eroded drumlins.

\section{Deglacial anatomy and ice-flow patterns during the Killard Point Stadial in Ireland}

The terrestrial sedimentary and dating records from the northwestern margin of the ISB are important because they show that ice accumulated and advanced during the Killard Point Stadial (Fig. 9). This ice readvance began after 14.7 and peaked at ca. $14.0{ }^{14} \mathrm{C}$ kyr BP following widespread deglaciation of the southern part of the ice sheet prior to $16.7{ }^{14} \mathrm{C}$ kyr BP (Fig. 9) (McCabe and Clark, 1998). The data show that the BIS participated in the North Atlantic H1 event.

Morphological and stratigraphical evidence supporting this widespread deglaciation and renewed regional ice advance comes from widely spaced sectors in central, western and northern parts of Ireland (Fig. 10):

1 Across the Irish midlands between The Derries and Athlone (ca. $80 \mathrm{~km}$ ) a west to east esker system records a major deglacial phase as ice withdrew westwards (Fig. 10) (McCabe, 1985; Delaney, 1995). Immediately north of Athlone a separate glacial system is recorded by north to south and northwest to southeast streamlined ridges and eskers that are stratigraphically later in age (Fig. 10). Satellite images (e.g. Fig. 4A) show that the flow lines of this system are coeval with those that terminated at ice limits in Dundalk Bay, $170 \mathrm{~km}$ to the northeast (Fig. 3). These morphological relationships therefore extend inland the spatial area that experienced the major deglaciation and ice readvance phases (Cooley Point interstadial followed by Killard Point Stadial) identified from the eastern Irish seaboard.

2 The precise distance the ice margin withdrew inland from the Irish Sea during the Cooley Point Interstadial is not known, although the absence of coarse-grained detritus in the muds around Dundalk Bay suggests ice retreated to the northwest. The presence, however, of an almost continuous zone of pristine flow-transverse ridges (Rogen moraines) across the north central lowlands $(<130 \mathrm{~m}$ a.s.l.) between Lurgan and Roscommon (ca. $150 \mathrm{~km}$ distance) suggests that the ice sheet did not disappear from this region altogether (Figs 4 and 10). These ridges are often asymmetric with steeper northwestern slopes and convex southeast-facing segments reflecting ice pressure from the northwest. Later ice streams moving southeastwards to ice limits in Dundalk Bay overprinted, remoulded and in places cut out the northeast-southwest 


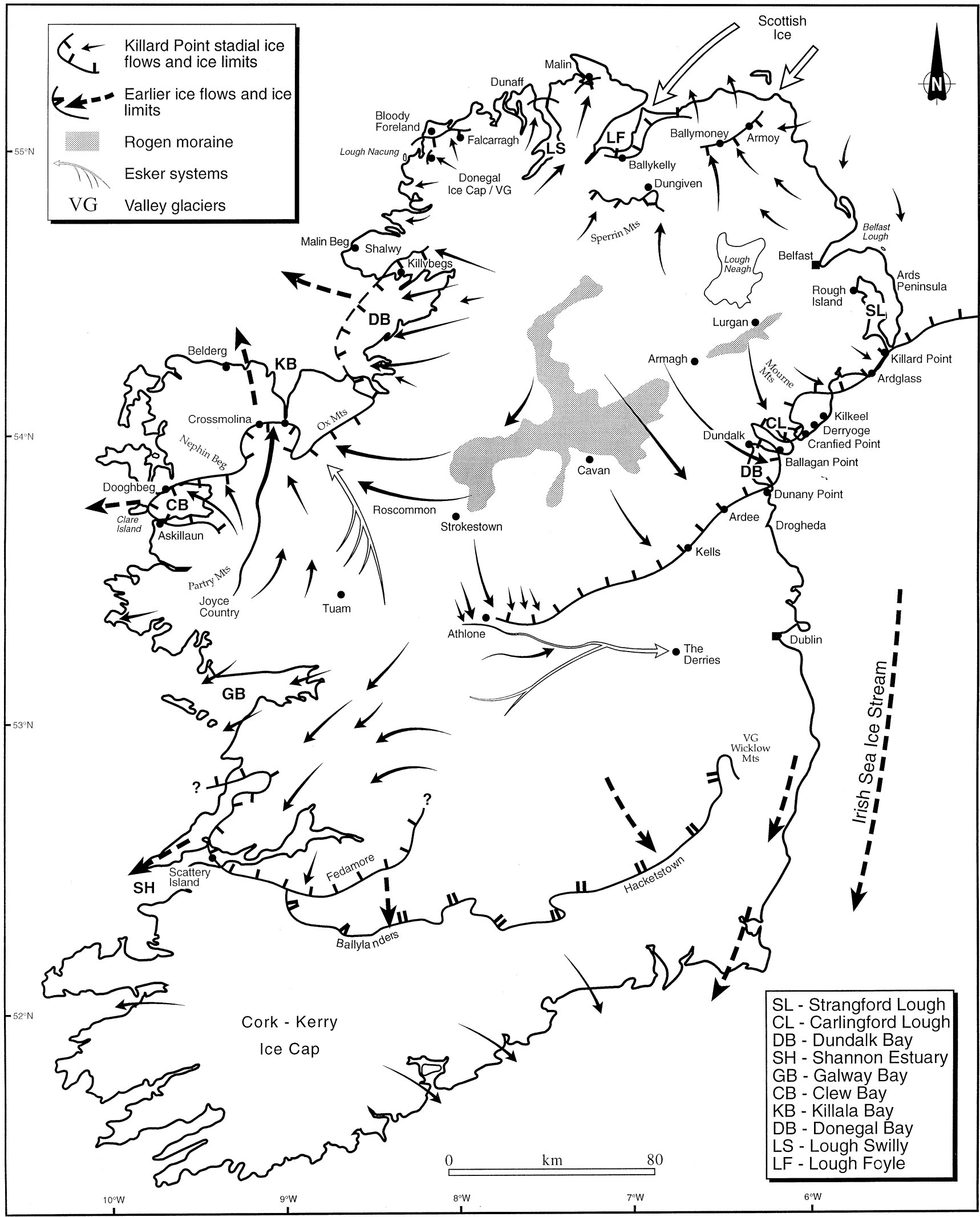

Figure 10 Ice flows and ice limits in Ireland recorded by bedform patterns formed during the last lowland ice-sheet oscillation (Killard Point Stadial). Older ice flows related to the LGM are also shown. The zone of preserved Rogen moraine is overprinted by bedforms associated with the final ice flow (see Fig. 4). Note that the Athlone-Derries esker system pre-dates the Killard Point Stadial and formed during the Cooley Point Interstadial. The Tuam esker system developed later and post-dates the maximum of the Killard Point Stadial (Rough Island Interstadial). 
topographic grain of the Rogen field (Fig. 3). This crosscutting relationship records a change in basal ice conditions at the onset of the ice readvance (Killard Point Stadial). The change probably involved a shift from a cold, dry-based ice sheet during or following Rogen formation (Lundquist, 1989) to warmer and wetter-based conditions during drumlinisation and headward (i.e. northwestwards) erosion of tidewater ice streams into the Rogen field (Figs 3 and $4 \mathrm{~A}$ ). The remarkable preservation of pristine Rogen ridges in north central Ireland suggests that parts of the ice mass remained cold based and that modification during drumlinisation was affected only by the most vigorous ice streams (Cavan, Armagh, Poyntz Pass, Banbridge) (Figs 3 and 10). The Killard Point Stadial readvance may have been driven initially by renewed ice accumulation, because this event followed a widespread deglaciation when the ice margin had withdrawn inland from the ISB (Fig. 10). It is therefore unlikely that the ice margin was influenced by tidewater processes or downdraw mechanisms at this time. This terrestrial record therefore discriminates between an initial accumulation-fed advance and a later sea-level trigger genetically associated with drumlinisation.

3 Satellite images (1:100 000 scale) show that ice flows during the Killard Point Stadial form contiguous and coeval bedform patterns across the Irish lowlands (Fig. 10). In some cases outliers of Rogen moraines are overprinted by these flowlines and provide information on the relative age of ice flowlines (Fig. 4A). This is important because the Killard Point Stadial was the last time that lowland ice overprinted earlier bedforms, which is marked by prominent morainic belts in western and northern Ireland (Fig. 10).

Moraine ridges in the Shannon estuary, as at Scattery Island, are composed of ice-thrust proglacial stratified sediments and diamicts (Fig. 10). The moraine (part of the Fedamore line; Synge, 1968) is located along the outer margins of colinear flow lines recorded by bedforms that have been streamlined from northeast to southwest from north central Ireland ice centres (130 km distance) (Fig. 10). The ice flows in this western sector are much longer than those in eastern Ireland (ca. $80 \mathrm{~km}$ ), which implies that the ice mass was asymmetric in long profile towards the west and northwest (Fig. 10).

At the head of Clew Bay composite bedforms consist of northeast-southwest trending ridges characterised by prominent concave embayments facing northwest, which are defined by curved tails or curved horns developed on both ends of the ridges (Fig. 11). The cores of the ridges (NESW aligned) consist of both glacial sediments and bedrock, which were moulded by west-going ice flow along the bay axis, possibly during the LGM. The northwest-pointing horns record the latest phase of ice overprinting and parallel the most recent set of glacial striae on the solid cores of the bedforms. Moraine ridges mark the marginal positions of this ice sheet oscillation (Fig. 10). At Askillaun on the south side of the bay an extensive (ca. $200 \mathrm{~m}$ wide) sediment apron (ca. $45 \mathrm{~m}$ thick) consists entirely of stacked, texturally variable diamict beds that dip consistently westwards (250$260^{\circ}$ ) and are probably of ice-proximal and glaciomarine origin (Synge, 1968; Hanvey, 1988). Moraine ridges on the eastern end of Clare Island and at Dooghbeg on the northern side of the bay represent the same ice limit (Fig. 10). East of Dooghbeg this ice limit is marked by an almost continuous east-west line of ice-contact marginal ridges at about $100 \mathrm{~m}$ a.s.l. Further inland this limit continues as multiple ridges within an arc that curves northwards on the lowlands to the east of the Nephin Beg range (Fig. 10). To the north, between Crossmolina and Ballina, this ice flow stage ended at an extensive area of hummocky topography (Fig. 10). Bedform patterns show south to north ice-flow lines that extend for $75 \mathrm{~km}$ from Joyce Country to Crossmolina. Regionally these ice flows are contemporaneous with those of the Killard Point Stadial identified to the east (Fig. 3). It is important to note that the ice-flow stage associated with the AskillaunDooghbeg and Crossmolina-Ballina moraines post-dates the extensive westward ice-sheet flow on to the continental shelf. Conventional radiocarbon dates from raised glaciomarine deposits at Belderg on the south side of Donegal Bay show that this flow stage pre-dates $16.6{ }^{14} \mathrm{C} \mathrm{kyr}$ BP (McCabe et al., 1986).

In Donegal Bay two subglacial bedform sets show a crosscutting pattern similar to that described from the head of Clew Bay (Knight and McCabe, 1997a). On the northern margin of the bay a prominent lateral moraine at Shalwy on the eastern slopes of Crownardd mountain borders the last bedform set. This subglacial bedform set can be traced inland for $60 \mathrm{~km}$ towards the same centres of ice dispersion that supplied ice to the Killard Point moraine (Fig. 10).

Possible ice limits related to the Killard Point Stadial from the north Donegal mountains are difficult to define precisely because ice limits of the local ice cap are strongly determined by topography, especially during periods of ice thinning (Fig. 10). The zones of terminal outwash associated with expanded valley glaciers at Lough Nacung, Bloody Foreland, Falcarragh, Dunaff and Malin, however, either ended in marine settings or are closely related to the highest lateglacial raised beaches (Stephens and Synge, 1965). It is argued from the known regional patterns of isostatic depression that all of the Killard Point Stadial ice limits in the north of Ireland are closely associated with high RSLs.

Terminal outwash ridges and spreads around Ballykelly record the southwesterly limit of ice from western Scotland which moved across the floor of the Malin Sea onto the coastal fringe of northeastern Ireland (Fig. 12A). The phasing relations between this advance and the last ice oscillation in the north of Ireland can be constrained from morphological evidence within the Dungiven depression, which opens northwards and is bounded to the south by the Sperrin Mountains (peaks ca. 600-800 m a.s.I.). Directional indicators show that ice during the Killard Point Stadial moved northwards through mountain cols but only reached the southern part of the Dungiven depression, depositing icecontact and extraglacial deltas in the upper Roe and Faughan valleys (Fig. 12B). These deltas record water ponding at a variety of heights $(<240 \mathrm{~m}$ a.s.I.). On the southern margin of Lough Foyle the Ballykelly moraine is related to ice from Scotland and is direct evidence for the ice dam that ponded water further south in the Roe and Faughan valleys. This field relationship indicates that these maximal ice limits were contemporaneous. An important inference is that separate centres of ice dispersion in southwest Scotland and north central Ireland were advancing at the same time. Further to the east, in north County Antrim, the Scottish (southwesterly) advance limit is recorded by a large morainic belt $(>70 \mathrm{~m}$ high) between Quilley, Ballymoney and Armoy. The belt contains erratics of Scottish provenance and large-scale glaciotectonic structures that indicate ice pressure from the north (Fig. 13). (Shaw and Carter, 1980). 


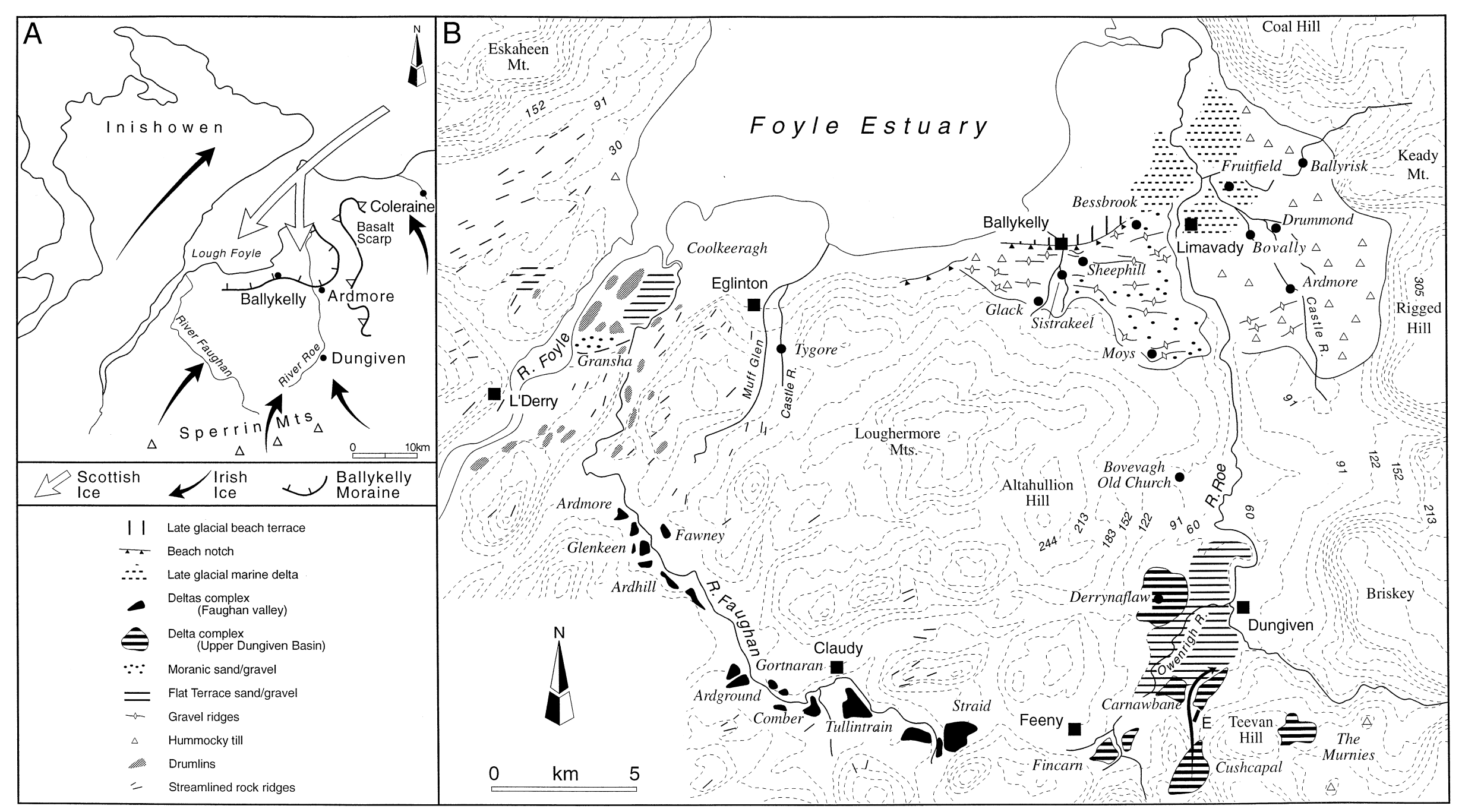

Figure 12 Glacial landforms and evidence for Killard Point Stadial ice limits around Lough Foyle, Northern Ireland. (A) Generalised ice flows in the areas bordering Lough Foyle, Northern Ireland during the Killard Point Stadial. (B) Glacigenic landforms on the Foyle lowlands and Dungiven depression. Contemporaneous ice limits are located at Ballykelly (Scottish ice) and along the northern margins of the Sperrin Mountains (Irish ice). 


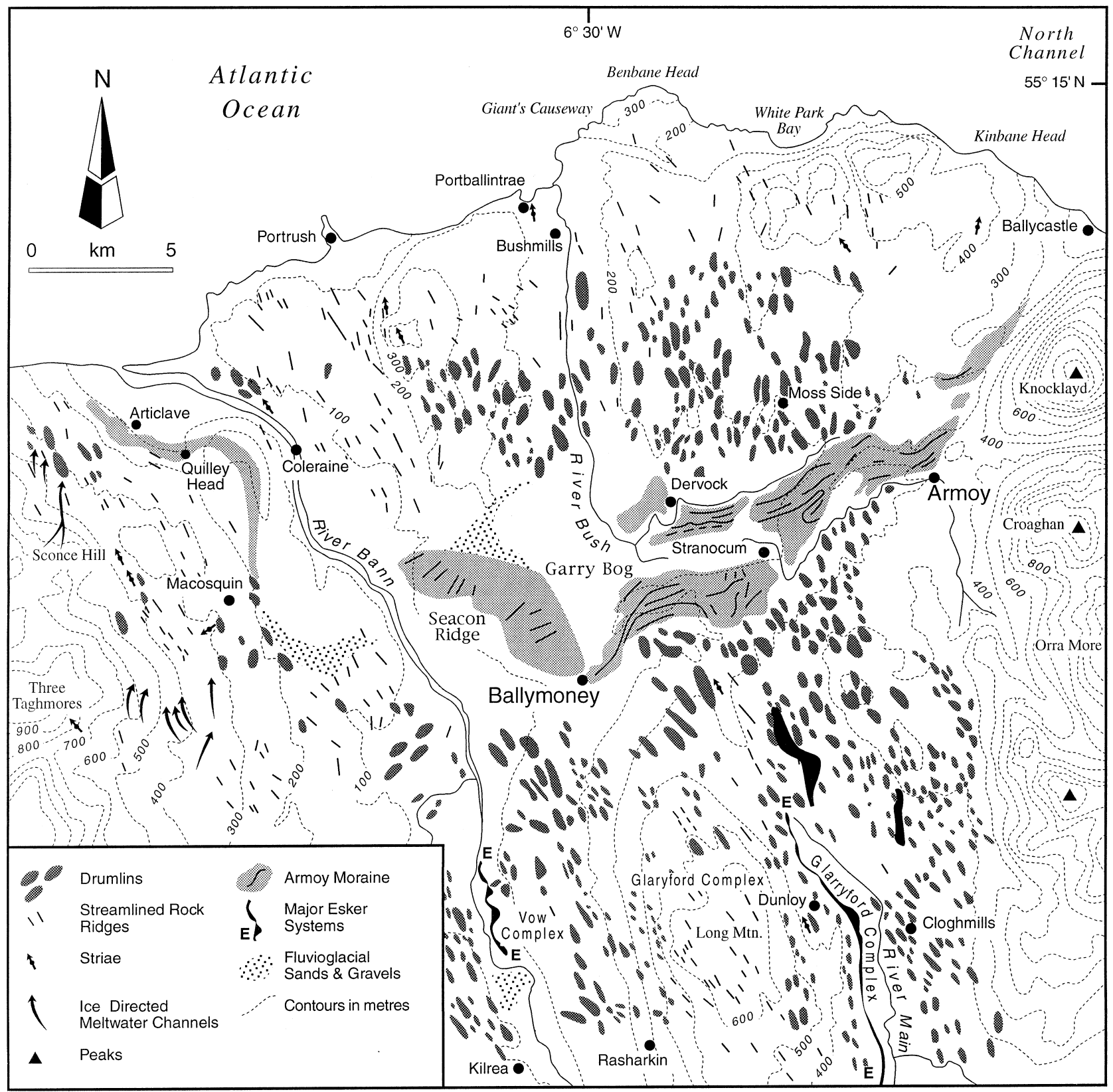

Figure 13 Relationships between subglacial bedforms and the Ballymoney-Armoy moraine, north County Antrim, Northern Ireland. Note that the subglacial streamlined bedforms maintain a similar orientation on both sides of the moraine.

\section{The Killard Point Stadial in the north Irish Sea area}

On the northern margins of the ISB regional ice-flow lines reconstructed from drumlins are also bounded by limiting moraines on the Isle of Man (Bride) and along the Cumbrian coast (St Bees-Drigg) (Fig. 1) (Trotter, 1929; Thomas, 1977; Huddart, 1994). The ice flows associated with these moraines are similar to the ice-sheet readvance during the Killard Point Stadial across eastern Ireland, and suggest a regional pattern of convergent ice flow southwards from separate ice dispersal centres into the northern ISB (Fig. 1). The moraines in this part of the basin are different structurally to the undeformed terminal outwash in eastern Ireland because they occur where ice margins impinged on bedrock ramps, causing the vertical duplication of stratigraphy by frontal thrusting and folding (Eyles and Eyles, 1984). Conformably bedded facies of diamict, sand, mud and gravel within the Bride moraine reveal the contemporaneous interplay between rain-out, traction currents, pelagic deposition, mass flow, subaqueous outwash and ice-rafting processes (Eyles and Eyles, 1984). The geometry of the Bride moraine is consistent with deposition on subaqueous aprons bulldozed in front of a tidewater ice margin (Eyles and McCabe, 1989). A similar picture of ice-proximal sedimentation and vertical duplication of stratigraphy occurs at St Bees, where the sediments are dominated by high-energy gravels. It is important to note that the proglacial deformation at St Bees created structural highs (ridges) and that the basal rhythmically bedded silt and sand infilling the inter-ridge basins formed in penecontemporaneous subaqueous settings (cf. Huddart, 1994). If the magnitudes of isostatic depression in Cumbria were similar to those already suggested for eastern Ireland at this time (McCabe, 1997) then the deposits forming the Bride and St Bees-Drigg moraines were either glaciomarine or influenced by water planes controlled by high RSLs (Eyles and McCabe, 1989). 
Along the Cumbrian coast, between St Bees and Seascale, morainic ridges subparallel to the coast represent thrusting at the lateral margin of ice located in the ISB itself (Fig. 1). The phase relationship between this ice mass and ice from local centres in the Lake District is shown from facies in a worked gravel pit at Peel Place, $3 \mathrm{~km}$ inland from Seascale. At this site cross-bedded gravel $(<7 \mathrm{~m}$ thick) forms part of an undulating outwash spread deposited at the terminus of an expanded valley glacier that moved southwestwards along the Wasdale trough (Fig. 1). The gravel facies is interbedded with thick $(<1 \mathrm{~m})$ beds of laminated and massive mud, which drapes the lowlands immediately to the west. Boreholes document up to $3 \mathrm{~m}$ of rhythmically bedded sediments in this area (ca. $4-5 \mathrm{~km}^{2}$ ) lying between these ice limits (G. Eaton, pers. comm., 1996). This field association suggests that mud deposition occurred when a substantial water body was impounded between contemporaneous ice limits at the coast and at the exit of Wasdale. This observation implies that local mountain ice and the Irish Sea ice sheet oscillations (from separate dispersion centres) were synchronous at this time.

\section{Ice sheet activity in Scotland during the Killard Point Stadial}

There is direct stratigraphical and morphological evidence from four areas in Scotland and on the adjacent continental shelf for a widespread ice readvance after $15{ }^{14} \mathrm{C}$ kyr BP but pre-dating the Loch Lomond Stadial readvance. This phase of ice-sheet activity can be correlated broadly with the Killard Point Stadial in the north Irish Sea area because of the scale of ice-sheet activity and the fact that ice dispersal centres in Scotland were a major contributor to the overall ice system in the north ISB and on the coast of northern Ireland.

1 The last phase of drumlinisation in southwestern Scotland is part of the regional ice system that readvanced southward along the North Channel into the north ISB and westwards on to the coastal fringe of northern Ireland (Fig. 14). Flow lines (ca. $150 \mathrm{~km}$ ) from this renewed phase of ice activity also end at moraines containing abundant erratics of Ailsa Craig microgranite and other acid igneous rocks of Scottish provenance.

2 A ${ }^{14} \mathrm{C}$ date on Portlandia arctica from a morainal bank on the continental shelf in the St Kilda basin provides a maximum age for this ice limit at $15.2{ }^{14} \mathrm{C}$ kyr BP (Peacock et al., 1992). This morainal bank records a substantial ice flux from an inferred ice axis near the Outer Hebrides $70 \mathrm{~km}$ to the east. The only ice-sheet advance of this magnitude on to the continental shelf recorded in the interval post-dating $15{ }^{14} \mathrm{C}$ kyr BP occurred during the Killard Point Stadial (Fig. 14).

3 In northeastern Scotland ridges and hummocks mark the limit of an ice-sheet readvance southwards from the Moray Firth across the Buchan coast to St Fergus (Fig. 14) (Hall and Jarvis, 1989; Peacock, 1997). The readvance postdates a more extensive glaciation when the Moray Firth ice stream extended east to the Bosies Bank moraine in the North Sea (Merritt et al., 1995). At St Fergus the morainic topography deposited by the Moray Firth ice stream overlies glaciomarine silts containing in situ shells of Hiatella arctica dated to $15320 \pm 200{ }^{14} \mathrm{C}$ yr BP (Hall and Jarvis, 1989). This single date suggests that the last oscillation of Moray Firth ice in this area post-dated 15 ${ }^{14} \mathrm{C}$ kyr BP (Peacock, 1997). Ice limits in the inner firth at Ardersier and Alturlie near Inverness record subsequent ice decay westwards (Merritt et al., 1995) (Fig. 14). These authors consider that the disintegration of the Moray Firth ice stream (with ice flowlines 160-180 km in length) was closely related to high RSLs and tidewater wastage. It is equally possible that the flowlines were sensitive to abrupt decreases in ice mass, which are expected at the end of a short-lived stadial $(<1000 \mathrm{yr}$ ) that terminated abruptly and was followed by a warm interstadial, as recorded elsewhere in the amphi-North Atlantic (Bond and Lotti, 1995).

4 In eastern Scotland the umbrella term Errol Beds is used to describe raised beds of clay, silt and sand often containing a distinctive mid-to-high Arctic fauna (Peacock, 1981). Because some clay beds are found to be interbedded with glacial outwash around Aberdeen (Peacock, 1975) the oldest facies must date from the decay phase following the last ice advance on to the shelf. It is also recognised that these facies are not deformed or overlain by major moraines. One radiocarbon date suggests that the western North Sea was deglaciated prior to $14{ }^{14} \mathrm{C}$ kyr BP (Hedges et al., 1988). Given the extent of ice-sheet activity during the Killard Point Stadial elsewhere in northern Britain, however, with flowlines of over $100 \mathrm{~km}$ in length, it is probable that ice advanced across the coast, which is located less than $80 \mathrm{~km}$ from the centres of greatest ice accumulation in the northwestern Highlands (Sissons, 1974).

The extensive spreads of ice-contact outwash at the heads of both the Forth and Tay estuaries are generally interpreted as dead-ice features (Simpson, 1933; Sissons, 1963, 1964, 1967; Patterson, 1974; Armstrong et al., 1975). These landforms together with the sediments comprising the extensive late-glacial Main Perth shorelines probably required direct glacigenic input into both the Tay and Forth estuaries. It is suggested that this input of sediment is related directly to the collapse of ice streams following ice advance into both estuaries during the Killard Point Stadial.

\section{Conclusions and implications}

The north ISB area is the type area for ice sheet readvance during the Killard Point Stadial in the British Isles. The dated facies successions are stratigraphically important because they provide the first direct terrestrial record that the BIS participated in H1 (McCabe and Clark, 1998). Stratigraphic evidence from in situ marine muds supported by $\mathrm{AMS}{ }^{14} \mathrm{C}$ dates provides a coherent time-frame for the major palaeoenvironmental shifts that occurred before, during and after ice readvance ca. $14{ }^{14} \mathrm{C}$ kyr BP (Table 1 ). These millennialscale shifts contrast with older, static models of Irish Sea glaciation, which are poorly age constrained and should be tested in terms of the rapid palaeoenvironmental changes identified in this paper.

During the Killard Point Stadial drumlinising ice flows were largely erosional and did not involve wholesale subglacial sediment deformation at an ice-sheet scale in north central Ireland. Northwest of Dundalk headward erosion along an ice stream into pristine Rogen moraine clearly supports this inference because elements of the former transverse Rogen ridges are fossilised within the drumlin field as flow-transverse lines of moulded comma-shaped and hooked 


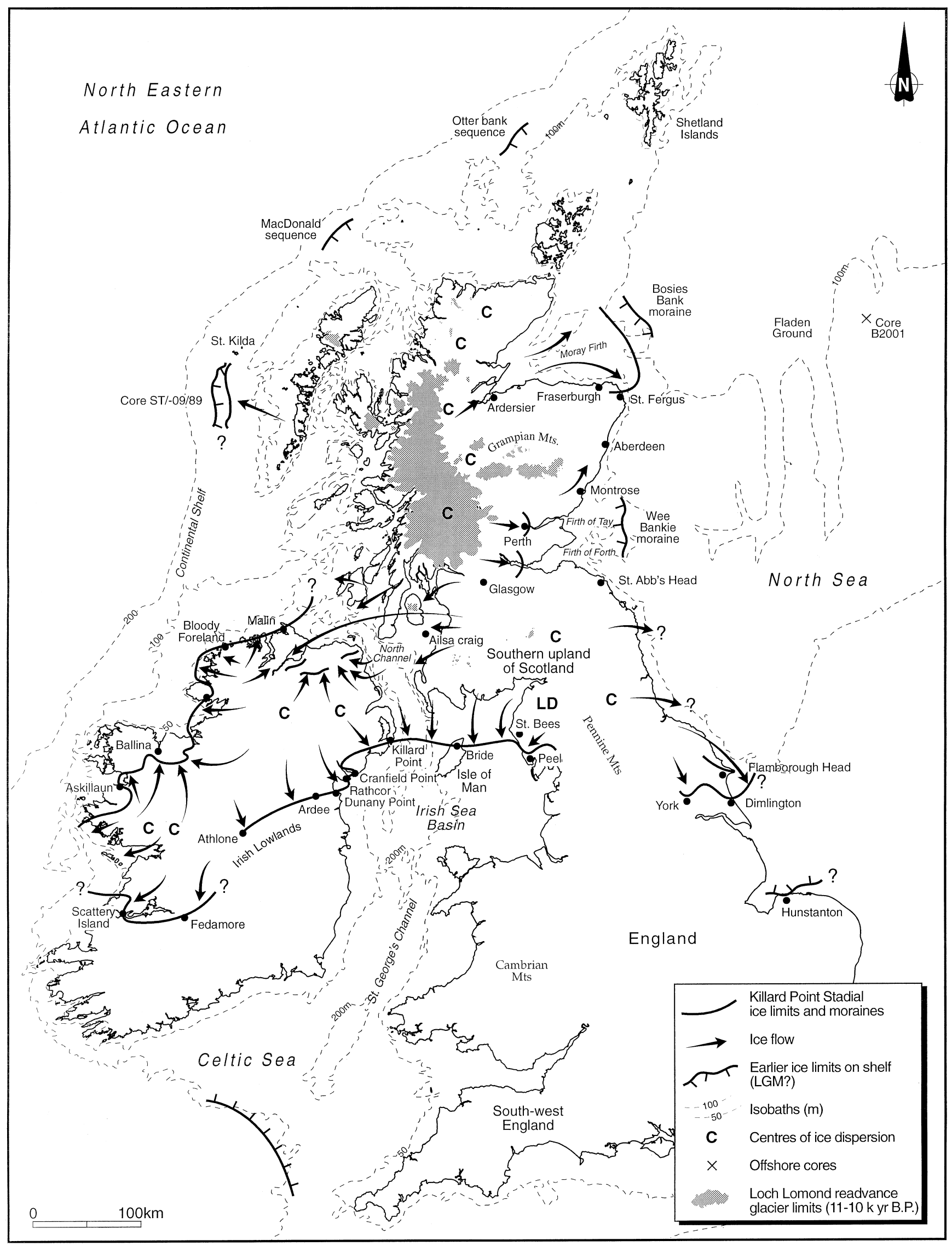

Figure 14 Generalised ice flows and ice limits during the $\mathrm{H} 1$ event in northern Britain $\left(\mathrm{ca} .14{ }^{14} \mathrm{C}\right.$ kyr BP). The extent of ice during the later Loch Lomond Stadial (Benn, 1997) and possible positions of the ice limits at the LGM are also shown. H1 ice limits in Scotland are poorly constrained. It is likely that the ice advanced into the North Sea during the $\mathrm{H} 1$ event and that the ice limits on land represent the decay and stabilisation/re-equilibration of the ice margin. 
bedforms (Figs. 3) (Knight and McCabe, 1997b). In addition marine downdraw must have had a destabilising effect on the ice sheet because all of the ice streams ended at tidewater margins. This process may have been especially critical towards the end of the readvance for two reasons. First, the geomorphological evidence shows that erosion along ice streams was not driven primarily by internal ice sheet dynamics but evolved by headward erosion back (i.e. northwestwards) from tidewater margins into the ice mass (Fig. 3). Second, the facies succession (intertidal boulder pavement $\rightarrow$ subaqueous outwash $\rightarrow$ late-glacial beach) at Cooley Point, immediately outside the ice limits, shows that high RSLs increased when the ice reached its maximum extent (Fig. 6) (McCabe and Haynes, 1996). Furthermore the presence of a regional drape of marine mud on drumlins and the absence of recessional fluvioglacial landforms inside the terminal outwash limits indicates that stagnation zone retreat occurred immediately after the readvance (Fig. 2).

The major deglaciation (Cooley Point Interstadial) that preceded ice readvance towards the ISB is also recorded from two widely spaced areas marginal to the ice sheet (Fig. 14). In western Ireland raised marine muds at Belderg (Fig. 2) are dated to $16.6{ }^{14} \mathrm{C} \mathrm{kyr} \mathrm{BP}$ and show that glaciomarine deposition occurred during a deglaciation that followed ice advance into Donegal Bay (McCabe et al., 1986). In the central North Sea (Fladen Ground, $200 \mathrm{~km}$ east of St. Fergus) Peacock (1997) has pointed out that environments recognised from borehole B2001 (Fig. 14) show that slow rates of marine deposition between 20 and $14.5{ }^{14} \mathrm{C}$ kyr BP were replaced by rapidly deposited glaciomarine sediments, especially between 14.5 and $14.2{ }^{14} \mathrm{C}$ kyr BP (Sejrup et al., 1994). These glaciomarine sediments indicate a marked increase in sediment input on to the shelf, which correlates closely with the maximum extent of ice during the Killard Point Stadial (ca. $14{ }^{14} \mathrm{C}$ kyr BP) (Table 1). In broad terms both of these records from eastern and western sectors of the former BIS underpin the evidence first recognised from the ISB that a major deglaciation occurred along the southern parts of the BIS around $17{ }^{14} \mathrm{C}$ kyr BP.

At Dimlington, the British late Devensian type site, mosses contained in shallow basins below till facies (Skipsea and Withernsea tills) are dated to 18.5 and $18.24{ }^{14} \mathrm{C}$ kyr BP (Penny et al., 1969). On this basis it was assumed that the late Devensian maximum in east Yorkshire occurred shortly after $18{ }^{14} \mathrm{C}$ kyr BP. Peacock (1997) questioned this interpretation because thermoluminescence dates of $17.5 \pm 1.5$ and $16.6 \pm 1.7 \mathrm{kyr}$ BP for a solifluction deposit underlying a correlative of the Skipsea till at Eppleworth $(40 \mathrm{~km}$ westnorthwest of Dimlington) suggest non-glacial conditions at this time (Wintle and Catt, 1985). Elsewhere in Britain dated facies records show only one major lowland ice readvance post-dating $16.7{ }^{14} \mathrm{C} \mathrm{kyr} \mathrm{BP}$. If this is the case it is probable that both the Skipsea and Withernsea tills are associated with ice flows on the margins of the North Sea that occurred during the Killard Point Stadial and not during the LGM. Morainic topography at Holderness (Valentin, 1957) records ice sheet limits that are similar in scale to the well-defined morainic ridges $50 \mathrm{~km}$ inland at York (Gaunt, 1976) and probably reflects the same ice-sheet event.

\section{H1 events in the amphi-North Atlantic}

The prominent BIS readvance at ca. $14{ }^{14} \mathrm{C}$ kyr BP allows important comparisons to be made with known events else- where in the amphi-North Atlantic (McCabe and Clark, 1998). For example, marine-based margins of the Barents Sea and Fennoscandian ice sheets began to retreat at ca. 15.0-14.7 ${ }^{14} \mathrm{C}$ kyr BP from their maximum positions, which they had maintained since the LGM (Jones and Keigwin, 1988; Lehman et al., 1991; Elverhoi et al., 1995). This deglaciation may be associated with rising sea-levels (Locker et al., 1996) or a reduction in precipitation at these latitudes associated with H1-related cooling in the North Atlantic region (Fawcett et al., 1997). In contrast, records from the southern margin of the Laurentide Ice Sheet (LIS) suggest that, following a major retreat that ended at $15.0-15.5{ }^{14} \mathrm{C}$ kyr BP (Erie interstade), the ice margin readvanced (Crown Point Phase of the Port Bruce Stade) several hundred kilometres to within $<150 \mathrm{~km}$ of its maximum late Wisconsin (Devensian) position and then retreated rapidly during or near the end of H1 (Hansel and Johnson, 1992; Clark, 1994). A similar sequence of events is recorded from the north ISB (Figs 2 and 3 and Table 1) and from around the margins of the decaying BIS. It is not known when the BIS began to advance, but the ISB data suggest it was at its maximum position at a time (ca. $14{ }^{14} \mathrm{C}$ kyr BP) when retreat of the southern margin of the LIS was well underway (McCabe and Clark, 1998).

The $\mathrm{H} 1$ event is an exception to the common relation between stadial climates and IRD events in the North Atlantic because it reversed a warming trend that began ca. 21000 calendar yr BP (ca. $18{ }^{14} \mathrm{C}$ kyr BP) (Bond and Lotti, 1995). Cooling occurred during $\mathrm{H} 1$ as a result of disruption of North Atlantic Deep Water (NADW) production by release of meltwater and icebergs (Keigwin et al., 1991; Keigwin and Lehman, 1994; Vidal et al., 1997). During $\mathrm{H} 1$ this warming trend was interrupted in the Northern Hemisphere and at least as far south as $40^{\circ} \mathrm{S}$ (Lowell et al., 1995; Bard et al., 1997) but continued in the Antarctic throughout the last deglaciation. This relationship to an overall warming trend is consistent with the suggestion by MacAyeal (1993) that the $\mathrm{H} 1$ event is associated with an inherent instability of the LIS that is independent of climatic forcing. If this is the case it is likely that partial collapse of the LIS leading to $\mathrm{H} 1$ induced North Atlantic cooling, which delayed the transition from full glacial to interglacial conditions north of the Antarctic convergence (Bard et al., 1997). In the British Isles the evidence for a major deglaciation (Cooley Point Interstadial) followed by rapid ice sheet growth $(\leq 700 \mathrm{yr}$, Killard Point Stadial) and then ice sheet collapse (Rough Island Interstadial) provides the field evidence that is consistent with this interpretation. In northwestern Britain a similar cooling occurred during the Loch Lomond Stadial (Sissons, 1979), which resulted in ice-sheet development in the Highlands of western Scotland that was simply smaller in scale to that of $\mathrm{H} 1$ (Fig. 14). Lehman et al. (1991) concluded that LIS iceberg discharge around $15{ }^{14} \mathrm{C}$ kyr BP resulted in North Atlantic cooling and suggests a climatic forcing and response that was similar to that recorded during the later Loch Lomond Stadial.

Acknowledgements We thank Drs C. Bryant and D. Harkness from the NERC Radiocarbon Laboratory, East Kilbride, for providing all of the AMS ${ }^{14} \mathrm{C}$ dates which constrain the facies data in this paper, and referees Professor C. Clapperton and Dr J. Scourse. Thanks are due to Killian McDaid and Mark Miller for computer drafting and Nigel McDowell for photography. This work was supported by the School of Environmental Studies, University of Ulster; particular thanks are due to Professor Eastwood for his support. Images used are courtesy of ERA-Maptec, Dublin. 


\section{References}

ARMSTRONG, M., PATERSON, I. B. and BROWNE, M. E. A. 1975. Late-glacial ice limits and raised shorelines in east central Scotland. IN: Gemmell, A. M. D. (ed.), Quarternary Studies in North East Scotland, 39-44. Department of Geography, University of Aberdeen.

AUSTIN, W. E. N. and MCCARROLL, D. 1992. Foraminifera from the Irish Sea glacigenic deposits at Aberdaron, western Lleyn, North Wales: paleoenvironmental implications. Journal of Quaternary Science, 7, 311-317.

BARD, E., ROSTEK, F. and SONZONGNI, C. 1997. Interhemispheric synchroneity of the last deglaciation inferred from alkenone paleothermometry. Nature, 385, 707-710.

BENN, D. I. 1997. Glacier fluctuations in western Scotland. Quaternary International, 38/39, 137-147.

BOND, G. and LOTTI, R. 1995. Iceberg discharges into the North Atlantic on millennial time scales during the last deglaciation. Science, 267, 1005-1010.

BOWEN, D. W., ROSE, J., McCABE, A. M. and SUTHERLAND, D. 1986. Correlation of Quaternary glaciations in England, Ireland, Scotland and Wales. Quaternary Science Reviews, 5, 299-340.

BROECKER, W. S. and DENTON, G. H. 1989. The role of oceanatmosphere reorganizations in glacial cycles. Geochimica et Cosmochimica Acta, 53, 2465-2501.

CLARK, P. U. 1994. Unstable behaviour of the Laurentide ice sheet over deforming sediment and its implications for climate change. Quaternary Research, 41, 19-25.

DANSGAARD, W., JOHNSEN, S. J., CLAUSEN, H. B., DAHLJENSEN, D., GUNDESTRUP, N. S., HAMMER, C. V., HVIDBERG, C. S., STEFFENSEN, J. P., SVINBJORNSDOTTIR, A. E., JOUZEL, J. and BOND, G. 1993. Evidence for general instability of past climate from a $250 \mathrm{kyr}$ ice core record. Nature, 364, 218-220.

DELANEY, C. 1995. Sedimentology of Late-Devensian deglacial deposits in the Lough Ree area, central Ireland. Unpublished PhD thesis, Trinity College, Dublin.

DIONNE, J. -C. 1981. A boulder strewn tidal flat, north shore of the Gulf of St. Lawrence, Quebec. Géographie Physique et Quaternaire, 35, 261-267.

ELVERHOI, A., ANDERSEN, E. S., DOKKEN, T., HEBBELN, D., SPIELHAGEN, R., SVENDSEN, J. I., SORFLATEN, M., RORNES, A., HALD, M. and FORSBERG, C. F. 1995. The growth and decay of the Late Weichselian ice sheet in western Svalbard and adjacent areas based on provenance studies of marine sediments. Quaternary Research, 44, 303-316.

EYLES, N. and EYLES, C. H. 1984. Glaciomarine sediments of the Isle of Man as a key to Late Pleistocene stratigraphic investigations in the Irish Sea Basin. Geology, 13, 446-447.

EYLES, N. and McCABE, A. M. 1989. The Late Devensian $(<22000$ BP) Irish Sea Basin: the sedimentary record of a collapsed ice sheet margin. Quaternary Science Reviews, 8, 307-351.

EYLES, N., MCCABE, A. M. and BOWEN, D. Q. 1994. The stratigraphic and sedimentological significance of Late Devensian ice sheet surging in Holderness, Yorkshire, U.K. Quaternary Science Reviews, 13, 727-759.

FAWCETT, P. J., AGUSTSDOTTIR, A. M., ALLEY, R. B. and SHUMAN, C. A. 1997. The Younger Dryas termination and North Atlantic Deep Water formation: insights from climate model simulations and Greenland ice cores. Paleoceanography, 12, 23-38.

GAUNT, G. D. 1976. The Devensian maximum ice limit in the Vale of York. Proceedings of the Yorkshire Geological Society, 40, 631-637.

HALD, M., STEINSUND, P. J., DOKKEN, T., KORSUN, S., POLYAK, L. and ASPELI, R. 1994. Recent and Late Quaternary distribution of Elphidium exclavatum f. cf. clavatum in Arctic seas. Cushman Foundation Special Publication, 32, 141-153.

HALL, A. M. and JARVIS, J. 1989. A preliminary report on the Late Devensian glaciomarine deposits around St. Fergus, Grampian region. Quaternary Newsletter, 59, 5-7.

HANSEL, A. K. and JOHNSON, W. H. 1992. Fluctuations of the Lake Michigan lobe during the Late Wisconsin subepisode. Sveriges Geologiska Undersokning, 81, 133-144.
HANVEY, P. M. 1988. The sedimentology and genesis of late Pleistocene drumlins in Counties Mayo and Donegal. Unpublished $\mathrm{PhD}$ thesis, University of Ulster, Jordanstown.

HAYNES, J. R., MCCABE, A. M. and EYLES, N. 1995. Microfaunas from Late Devensian glaciomarine deposits in the Irish Sea basin. Irish Journal of Earth Sciences, 14, 81-103.

HEDGES, R. E. M., HOUSLEY, R. A., LAW, I. A., PERRY, C. and HENDY, C. 1988. Radiocarbon dates from the Oxford AMS System: Archaeometry Datelist 9. Archaeometry, 30, 291-305.

HEIN, F. J. 1982. Depositional mechanisms of deep-sea coarse clastic sediments, Cap Enrange Formation, Quebec. Canadian Journal of Earth Sciences, 19, 267-287.

HUDDART, D. 1994. The late Quaternary glacigenic sequence: landforms and environments in coastal Cumbria. IN: Boardman, J. and Walden, J. (eds), Cumbria Field Guide, 57-77. Quaternary Research Association, Oxford.

JONES, G. A. and KEIGWIN, L. D. 1988. Evidence from Fram Strait $\left(78^{\circ} \mathrm{N}\right)$ for early deglaciation. Nature, 336, 56-59.

KEIGWIN, L. D., JONES, G. A., LEHMAN, S. J. and BOYLE, E. A. 1991. Deglacial meltwater discharge, North Atlantic deep circulation, and abrupt climate change. Journal of Geophysical Research, 96, 16 811-16826.

KEIGWIN, L. D. and LEHMAN, S. J. 1994. Deep circulation change linked to Heinrich event 1 in a mid-depth North Atlantic core. Paleoceanography, 9, 185-194.

KNIGHT, J. and McCABE, A. M. 1997a. Drumlin evolution and ice sheet oscillations along the NE Atlantic margin, Donegal bay, western Ireland. Sedimentary Geology, 111, 57-72.

KNIGHT, J. and MCCABE, A. M. 1997b. Identification and significance of ice-flow-transverse subglacial ridges (Rogen moraines) in north central Ireland. Journal of Quaternary Science, 12, 519-524.

KNIGHT, J., McCARRON, S. G. and McCABE, A. M. 1997. Geologic evidence for controls on late Pleistocene ice activity cycles in Ireland. EOS (Transactions of the American Geophysical Union), Supplement, 78, F248.

LEHMAN, S. J., JONES, G. A., KEIGWIN, L. D., ANDERSEN, E. S., BUTENKO, G. and OSTMO, S. R. 1991. Initiation of Fennoscandian ice-sheet retreat during the last deglaciation. Nature, 349, 513-516.

LOCKER, S. D., HINE, A. C., TEDESCO, L. P. and SHINN, E. A. 1996. Magnitude and timing of episoidic sea-level rise during the late deglaciation. Geology, 24, 827-830.

LOWE, D. R. 1976. Subaqueous liquefied and fluidized flows and their deposits. Sedimentology, 23, 285-308.

LOWE, D. R. 1982. Sediment gravity flows, II. Depositional models with special reference to the deposits of high-density turbidity currents. Journal of Sedimentary Petrology, 52, 279-297.

LOWELL, S. D., HEUSSER, C. J., ANDERSEN, B. G., MORENO, P. I., HAUSER, A., HAUSER, L. E., SCHLUCHTER, C., MARCHANT, D. R. and DENTON, G. H. 1995. Interhemispheric correlation of late Pleistocene events. Science, 269, 1541-1549.

LUNDQVIST, J. 1989. Rogen (ribbed) moraine-identification and possible origin. Sedimentary Geology, 62, 281-292.

MacAYEAL, D. R. 1993. Growth/purge oscillations of the Laurentide ice sheet as a cause of the North Atlantics Heinrich events. Paleoceanography, 8, 775-784.

MACKIEWICZ, N. E., POWELL, R. D., CARLSON, P. R. and MOLINA, B. 1984. Interlaminated ice-proximal glaciomarine sediments in Muir inlet, Alaska. Marine Geology, 57, 113-147.

McCABE, A. M. 1985. Geomorphology. IN: Edwards, K. J. and Warren, W. P. (eds), The Quaternary History of Ireland, 67-93. Academic Press, London.

MCCABE, A. M. 1986. Glaciomarine facies deposited by retreating tidewater glaciers - an example from the Late Pleistocene of Northern Ireland. Journal of Sedimentary Petrology, 56, 880-894.

McCABE, A. M. 1996. Dating and rhythmicity from the last deglacial cycle in the British Isles. Journal of the Geological Society, London, 153, 499-502.

McCABE, A. M. 1997. Geological constraints on geophysical models of relative sea-level change during deglaciation of the western Irish Sea basin. Journal of the Geological Society, London, 154, 601-604.

McCABE, A. M. and CLARK, P. U. 1998. Ice sheet variability around 
the North Atlantic Ocean during the last deglaciation. Nature, 392, 373-377.

McCABE, A. M. and HAYNES, J. R. 1996. A Late Pleistocene intertidal boulder pavement from an isostatically depressed emergent coast, Dundalk bay, eastern Ireland. Earth Surface processes and Landforms, 21, 555-572.

McCABE, A. M., DARDIS, G. F. and HANVEY, P. M. 1984. Sedimentology of a Late-Pleistocene morainic complex, County Down, Northern Ireland. Journal of Sedimentary Petrology, 56, 716-730.

McCABE, A. M., HAYNES, J. R. and MACMILLAN, N. F. 1986. Late Pleistocene tidewater glaciers and glaciomarine sequences from north County Mayo, Republic of Ireland. Journal of Quaternary Science, 1, 73-84.

McCABE, A. M., DARDIS, G. F. and HANVEY, P. M. 1987. Sedimentology at the margins of a Late-Pleistocene ice-lobe terminating in shallow marine environments, Dundalk Bay, eastern Ireland. Sedimentology, 34, 473-493.

McCABE, A. M., DARDIS, G. F. and HANVEY, P. M. 1992. Glacial sedimentology in northern and western Ireland. Pre- and Postexcursion Field Guide Book, Anglia Polytechnic, Cambridge, 238 pp.

MCCARROLL, D. and HARRIS, C. 1992. The glacigenic deposits of western Lleyn, north Wales: terrestrial or marine? Journal of Quaternary Science, 7, 19-29.

MERRITT, J. W., AUTON, C. A. and FIRTH, C. R. 1995. Iceproximal glaciomarine sedimentation and sea level change in the Inverness area, Scotland: a review of the deglaciation of a major ice stream of the British Late Devensian ice sheet. Quaternary Science Reviews, 14, 289-329.

MIDDLETON, G. V. and HAMPTON, M. A. 1976. Subaqueous sediment transport and deposition by sediment gravity flows. IN: Stanley, D. G. and Swift, D. J. P. (eds), Marine Sediment Transport and Environmental Management, 197-218. Wiley, New York.

PATTERSON, I. B. 1974. The supposed Perth Readvance in the Perth district. Scottish Journal of Geology, 10, 53-66.

PEACOCK, J. D. 1975. Scottish late and post-glacial marine deposits. IN: Gemmell, A. M. D. (ed.), Quaternary Studies in North East Scotland, 45-48. Department of Geography, University of Aberdeen.

PEACOCK, J. D. 1981. Scottish Late-glacial marine deposits and their environmental significance. IN: Neale, J. and Flenley, J. (eds), The Quaternary in Britain, 222-236. Pergamon Press, Oxford.

PEACOCK, J. D. 1997. Was there a readvance of the British ice sheet into the North Sea between $15 \mathrm{ka}$ and $14 \mathrm{ka}$ BP? Quaternary Newsletter, 81, 1-8.

PEACOCK, J. D., AUSTIN, W. E. N., SELBY, I., GRAHAM, D. K., HARLAND, R. and WILKINSON, I. P. 1992. Late Devensian and Flandrian palaeoenvironmental changes on the Scottish continental shelf west of the outer Hebrides. Journal of Quaternary Science, 7, 145-161.

PENNY, L. F., COOPE, G. R. and CATT, J. A. 1969. Age and insect fauna of the Dimlington silts, east Yorkshire. Nature, 224, 65-67.

POSTMA, G., NEMEC, W. and KLEINSPEHN, K. 1988. Large floting clasts in turbidites: a mechanism for their emplacement. Sedimentary Geology, 58, 47-61.

ROSE, J. 1985. The Dimlington Stadial/Dimlington Chronozone: a proposal for naming the main glacial episode of the Late Devensian in Britain. Boreas, 14, 225-230.
SEJRUP, H. P., HAFLIDASON, H., AARSETH, I., KING, E., FORSBERG, C. F., LONG, D. and ROKOENGEN, K. 1994. Late Weichselian glaciation history of the northern North Sea. Boreas, 23, 1-13.

SHAW, J. and CARTER, R. W. G. 1980. Late-Midlandian sedimentation and glaciotectonics of the north Antrim end moraine. Irish Naturalists' Journal, 20, 67-69.

SIMPSON, J. B. 1933. The late-glacial readvance moraines of the highland border west of the river Tay. Transactions of the Royal Society of Edinburgh, 57, 633-646.

SISSONS, J. B. 1963. The Perth readvance in central Scotland. Part 1. Scottish Geographical Magazine, 79, 151-163.

SISSONS, J. B. 1964. The Perth readvance in central Scotland. Part 2. Scottish Geographical Magazine, 80, 28-36.

SISSONS, J. B. 1967. Glacial stages and radiocarbon dates in Scotland. Scottish Journal of Geology, 3, 375-381.

SISSONS, J. B. 1974. The Quaternary in Scotland: a review. Scottish Journal of Geology, 10, 311-337.

SISSONS, J. B. 1979. The Loch Lomond Stadial in the British Isles. Nature, 280, 199-203.

STEPHENS, N. 1963. Late-glacial sea levels in north-east Ireland. Irish Geography, 4, 345-359.

STEPHENS, N. and McCABE, A. M. 1977. Late-Pleistocene ice movements and patterns of late- and post-glacial shorelines on the coast of Ulster. IN: Kidson, C. and Tooley, M. J. (eds), Quaternary History of the Irish Sea, 179-198. Seel House Press, Liverpool.

STEPHENS, N. and SYNGE, F. M. 1965. Late-Pleistocene shorelines and drift limits in north Donegal. Proceedings of the Royal Irish Academy, 64B, 131-153.

SYNGE, F. M. 1969. The Wurm ice limit in the west of Ireland. IN: Wright, H. E., Jr. (ed.), Quaternary Geology and Climate, Publication 1701, 89-92. National Academy of Sciences, Washington, DC.

SYNGE, F. M. 1968. The glaciation of west Mayo. Irish Geography, 5, 372-386.

THOMAS, G. S. P. 1977. The Quaternary of the Isle of Man. IN: Kidson, C. and Tooley, M. J. (eds), Quaternary History of the Irish Sea, 155-178. Seel House Press, Liverpool.

TROTTER, F. M. 1929. The glaciation of the eastern Edenside, Alston block and the Carlisle plain. Quarterly Journal of the Geological Society of London, 88, 549-607.

VALENTIN, H. H. 1957. Glazial morphologische undersuchungen in Ostengland. Abhandlugen der Geographische Institut der Freien Universitat, Berlin, 4, 1-86.

VIDAL, L., LABEYRIE, L., CORTIJO, E., ARNOLD, M., DUPLESSY, J. C., MICHEL, E., BECQUE, S. and VAN WEERING, T. C. E. 1997. Evidence for changes in the North Atlantic Deep Water linked to meltwater surges during Heinrich events. Earth and Planetary Science Letters, 146, 13-27.

VILKS, G. 1981. Late glacial-post glacial foraminiferal boundary in sediments of eastern Canada, Denmark and Norway. Geoscience Canada, 8, 48-56.

WALKER, R. G. 1975. Generalised facies models for resedimented conglomerates of turbidite association. Geological Society of America Bulletin, 88, 273-285.

WINTLE, A. G. and CATT, J. C. 1985. Thermoluminescence dating of Dimlington Stadial deposits in eastern England. Boreas, 14, 231-234. 